\title{
Theology of Veneration of the Prophet Muhammad
}

\author{
Knowledge and love in the Shifā of al-Qā \\ hadith, philosophy and spirituality
}

\author{
Ruggero Vimercati Sanseverino
}

\section{Rethinking the Scope of Sunnī Prophetological Discourse}

It suffices for the intelligent reader to realise that we did not collect all that is in our book for those who deny the prophethood of our Prophet, or for those who slander on his miracles, so that we would need to engage in proofs [...], but we wrote it for the people of the Prophet's community who respond to his call and believe in his prophethood, in order to affirm their love for him (ta'kidan li-mahabbatihim lahu) and that their deeds may increase and their faith be reinforced. ${ }^{1}$

The Moroccan Mālikī scholar Abū al-Faḍl 'yyāọ al-Yaḥ̣ubī² (d. 544/1149), com-

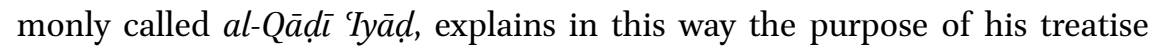
al-Shifä' bi-ta'rīf huqūq al-Musțafā ("The healing through the recognition of the rights of the chosen Prophet"), which can rightly be considered the major reference text of Sunnī prophetology and one of the most widely read and diffused works in the history of Islamic literature. Despite this explicit indication of the author, studying the Shif $\tilde{a}^{\text {' }}$ with regard to its purpose to induce the love for the Prophet in the Muslim community has not yet attracted any attention in academic research on this important work. As astonishing as this might seem, it is, in fact, understandable when bearing in mind the background from which the general theme of the Shif $\vec{a}^{\prime}$ - that is, the veneration of the Prophet - has been considered. Just to give a few examples, even for such a sensitive observer like the Neo-Thomist historian of Muslim theology Louis Gardet, the veneration of the Prophet has its basis in the dichotomy between

1 'Iyād, Shifä', 15o. Translations are by the author. There are a variety of non-academic translations into major Western languages, for example in English with the Arabic text by Hibah, Ash-Shifa.

2 See in particular Serrano, "Iyāḍ" and as primary sources, 'Iyāḍ, Tárīf and Maqqarī, Azhār al-riyāẹ. 
popular and learned Islam, and is clearly a phenomenon related to the first. ${ }^{3}$ More recently, Tilman Nagel opts for an Islamicised version of the "priest fraud" theory ("Priesterbetrugstheorie") and argues the other way around, namely that the veneration of the Prophet was constructed by the 'ulama $\bar{a}$ in order to enforce Islamic norms on the Muslim community: The Muhammadglauben ("belief in Muhammad") and its implied veneration of the Prophet serves in fact the "self-reassurance" (Selbstvergewisserung) of the Muslim masses. ${ }^{4}$ Both theses, which underly a large proportion of academic writing about Muslim attitudes towards the Prophet, have the idea in common that the veneration of the Prophet, and the belief in his pre-eminence, serve to fulfil, in one way or another, the needs of the uneducated and uncritical Muslim masses; hence, they do not represent a genuinely theological or intellectual theme of Islamic thought. ${ }^{5}$

It is not surprising, then, that against this background, the veneration of the Prophet has, with notable exceptions, ${ }^{6}$ not attracted much interest in academic research until recent political events made evident the mobilising force

3 Gardet, Théologie musulmane, 201. He equally speaks of a Muslim "hyperdulia cult" (226-27) and argues that "the absolute pre-excellence of the Prophet upon any creature does not enter the usual perspective of kalam" (206). I would argue that this thesis can be traced back to the influence of protestant biblical studies and its theory of the "biographical process" on early orientalism, as exemplified by Josef Horovitz's "The Growth of the Mohammed Legend" of 1920. See also Van Ess, Miriāj, 27-28 who credits early Islam with having been less affected with a subsequently constructed exaltation of its founder than early Christianity, but at the same time closes his study with the remark that "it was resolutely decided to exalt him, but the events of his life had already anticipated this exaltation" (Mirräj, 56).

4 Nagel, Allahs Liebling. Tilman Nagel, for whom the Shifä" establishes "Muhammad as the source of Muslims' production of meaning and existential determination" (Allahs Liebling, 22), devotes a whole chapter to the Shifä' in his study, under the title "The dogmatisation of the prophetic vita" (135-98), albeit without discussing its central notions and concepts, and from his particular, sometimes polemical perspective.

5 One could add that this sociological preconception, founded on the dichotomy between learned and popular Muslims, is more or less consciously associated with a historical one according to which the veneration of the Prophet does not belong to the "original Islam", the latter being sharply distinguished from Islam as constructed by Muslim traditions. It is interesting to note, however, how this conception of "original Islam" does represent numerous similarities with the Neo-Salafist concept of "the Islam of the origins".

6 Besides the pioneering work of Tor Andrae of 1918, notably not a scholar of Islamic studies in the first place but a theologian and a historian of religions, it is above all the specialists of Sufism who have been interested in this theme. See in particular Schimmel, Und Muhammad (1981), Chodkiewicz, "Modèle prophétique" (1994); Gril, "Corps du Prophète" (2006); Katz, Birth of the prophet (2007) and Addas, Maison du Prophète (2015). 
of the reference to the Prophet, ${ }^{7}$ in this way pushing academia to acknowledge the necessity of obtaining a deeper understanding of Muslims' relationship to their Prophet. ${ }^{8}$ What applies to the theme of veneration of the Prophet is even more true for the notion of love (mahabba) as the evident core of an attitude of veneration for the Prophet, despite its being ever-present in Islamic literatures and cultures. Far from representing merely a moral or sentimental device for the masses, love for the Prophet is the notion through which Islamic sources, beginning with the Qurān and the hadith, ${ }^{9}$ qualify the relationship of the Muslim community to its founding figure and the normative character of its commitment and reconnection to him. ${ }^{10}$

As the Shifä illustrates, the concept of mahabbat al-nabi is part of a highly sophisticated scholarly discourse which traverses various Islamic disciplines and traditions. So besides being a genuinely theological issue, the veneration of the Prophet constitutes also a topos which relies heavily on the hadith tradition, on philosophical thought and on Muslim spirituality. With about 1800 narrations, the Shifä draws heavily on the corpus of Prophetic Tradition and adopts in many ways the views of traditionalist scholarship which became prominent amongst "reformed" Māliki scholars of this period." But although the Shifä' is sometimes referred to as a work of hadith or sira, it is far more than a simple thematic or biographical anthology in the framework of that

7 In the first place, the Danish caricature affair of 2005 and the jihadist justification of terrorist activities through the figure of the Prophet, beginning with al-Qācida and leading to IsIs. See Vimercati Sanseverino, Combat Prophetology.

8 Since Annemarie Schimmel's groundbreaking Und Muhammad ist Sein Prophet (1981, English translation 1985), there has been a flourishing of monographs presenting historical outlines of the Muslim view of the Prophet for a wider readership, beginning with Schöller, Mohammed (2008); Khalidi, Images of Muhammad (2009); Safi, Memories of Muhammad (2010); Brown, Muhammad (2011); Ali, Lives of Muhammad (2014). See also Görke, "Introduction", 2015.

9 In Q 9:24, probably addressed to "those Muslims who remained in Mecca after the migration" (Study Quran, 511), love for the Prophet Muhammad, here in the sense of giving preference to him, appears as a mark which distinguishes his most loyal followers: "Say: 'If your fathers, your children, your brothers, your spouses, your tribe, your wealth you have acquired, commerce whose stagnation you fear, and dwellings you find pleasing are more beloved to you than God and His Messenger (ahabba ilaykum min Allāh wa rasūlihi), and striving in His way, then wait till God comes with His command' [...]". Examples from the hadith are certainly more numerous, the most famous being the tradition found, amongst others, in Bukhārī, Șạīh, kitāb al-īmān, bāb hubb al-rasūl min al-īmān, $\mathrm{N}^{\circ}$ 14, "Nobody has faith until he loves me more than his father, his child and the whole of mankind". See also in particular Gril, "Attitude des Compagnons".

10 For the paradigmatic significance of the reconnection to the Prophet, see Graham, "Traditionalism".

See Fierro, "Proto-Malikis". 
literature. Its thematic and argumentative structure appears to be determined by a sophisticated theological reasoning, ${ }^{12}$ partly influenced by philosophical thought and by notions from Islamic spirituality.

The text of the Shifä is organised in four larger parts (aqsām) which cover both doctrinal and practical aspects of Islamic prophetology. The first part is concerned with the status and rank of the Prophet Muhammad and includes sections on Qurānic evidence, on his miracles, on his virtuous and physical appearance or his announcement in previous religious scriptures. This part is informed by various genres of prophetological discourse and literature and is primarily exegetical, although it also includes elements from philosophical ethics and purely prophetological considerations inspired by tașawwuf or kaläm. The second part is dedicated to the "rights of the Prophet" and expounds how Muslims should behave towards their Prophet, and which attitude they should adopt. This part in fact develops practical consequences of the pre-eminence of the Prophet and elaborates on the implementation of its meaning for Muslims. It represents the most unique and original part of the Shifä, as it draws on such varied discourses and genres as kaläm, figh and tașawwuf. In particular, one has to note a very long part on the theme of love for the Prophet, probably pioneering in Islamic literature. Part three deals with the prophetic reality of Muhammad and its theological articulation in terms of what must be affirmed about the Prophet, what is impossible to affirm and what can be possibly affirmed with regard to him. This part represents a classical kalām approach to prophetology, but with a particular focus on the crucial question of the relationship between the human nature and the prophetic authority of Muhammad. ${ }^{13}$ The theme of the Prophet's impeccability and infallibility is treated in detail, including for example the issue of the so-called "Satanic Verses". ${ }^{14}$ The last and fourth part discusses the violation of the rights of the Prophet and is concerned with the normative regulations concerning blasphemy. Hence, it deals with the collective implementation of the rights of the Prophet and their social and political aspects, and addresses more specifically the duties of an Islamic government. Unlike the other chapters, it is characterised by a purely figh approach. But again, with regard to this topic,

12 Interestingly, the "secret" (sirr) of the work, as the author himself explains in the introduction (Shifä, 16), is to be found in the third part which develops the classical kaläm theme of nubuwwāt (prophetology) and discusses in particular the complex relationship between the human nature of Muhammad and his prophetic authority.

13 See Vimercati Sanseverino, „Wer dem Gesandten gehorcht“, 63-38.

14 'Iyād, Shifä', 294-299. For this issue, see the study by Ahmad, Before Orthodoxy. 
the Shif $\bar{a}$ is recognised as one of the reference works, with a particularly severe stance against blasphemy. ${ }^{15}$

This concise overview shows how the Shifä draws on multiple types of literature and discourse about the Prophet Muhammad in order to present a coherent, comprehensive and systematic prophetological work. ${ }^{16}$ But al-Qāḍī 'Iyād does not contend himself to merely collect and compile these elements. He uses these in a new way, developing a new approach to prophetology, and therefore, besides synthesising what was before him, he at the same time marks a new phase of prophetological writing. Whereas previous literature was chiefly concerned with either the significance or the content of the prophetic teaching and mission, the Shif $\tilde{a}^{\prime}$ focuses on the person of the Prophet and its meaning for religious life. ${ }^{17}$ In this way, the author endeavors to offer, in the context of dramatic political and religious upheavals, ${ }^{18}$ an answer to the following interrogation: how should Muslims, individually and collectively, relate to their Prophet, and what meaning does this relationship have? In other words: what kind of relationship should Muslims have to their Prophet?

As a synthesis and culmination of a discursive tradition concerning the Prophet Muhammad in Sunnī Islam, the Shifä̉ represents a landmark in the history and literature of "Prophetic piety"19 or "Muhammadan spirituality"20 and prophetology. It has been extensively referred to in academic research, mainly

15 On this topic see Wagner, "Non-Muslims who insult", and Nagel, "Tabuisierung". Kattānī (Madkhal, 188-193) collected statements of scholars who refrained from reading this part in public for "fear for the laymen (khawfan 'alā al-'āmma)".

16 Shawwāt, 'Alim al-maghrib, 117-54, offers a list of sources from various disciplines used by al-Qāḍi 'Iyāḍ based on analysis of the Ghunya, the Shifä', his commentary on Muslim's hadìth compilation and his hadīth handbook.

17 This is evident for the hadith literature as well as for the sirra and the daläil al-nubuwwa literature. As for the shamäil literature, which is indeed concerned with the description of the person of Muhammad, it does not offer any theological elaboration on the soteriological, eschatological or spiritual significance of the prophetic person. This step is undertaken in the Shifä, as will be shown later.

18 In the present study, we will not dwell upon the historical circumstances which motivated or influenced the redaction of the Shifä. Besides the already existing studies (see below), a further study on this important question, considering in particular al-Qāḍī 'Iyāụ's project of a revival of Sunnì identity against the politico-religious developments of his time, is currently in preparation.

19 We owe this helpful expression to Stefan Reichmuth; see Reichmuth, "Prophetic Piety". The Shifä' certainly needs to be considered as participating in the profusion of prophetological writing in al-Andalus in the fourth-seventh/tenth-thirteenth centuries. On this last phenomenon, see Jarrar, Prophetenbiographie and Fierro, "Kitāb al-anwār".

20 This expression is used by Tilman Nagel to describe the transition from "Sunnī piety" to a spirituality characterised by its strong reference to the Muhammadan personality in the sixth/twelfth century. According to Nagel, this evolution explains how the inviolability of 
by historians of al-Andalus who are interested in the religious-political context of the Islamic West during the Almohad period and who have insisted on the polemical scope of the Shif $\bar{a}^{2},{ }^{21}$ as well as by historians of Muslim thought and literature who have referred to the Shifa $\vec{a}^{\prime}$ as an important source for the history of representations of the Prophet. ${ }^{22}$ However, a systematic and in-depth study of its theological concepts and argumentation or of the use of sources and discursive traditions, remains a desideratum. While not pretending to fill this gap in an exhaustive manner, this study focuses on two core themes of the

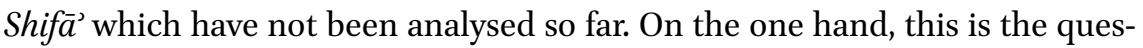
tion of man's knowledge of the Prophet's status, dignity and reality, and of the conditions and sources of this knowledge. On the other hand, corresponding to the purpose of the work according to its author, it is the theme of love for the Prophet, its meaning and its normative character. As the study will show, both themes are in fact interconnected, and the argument of the Shifä, as well as the issue of the veneration of the Prophet in general, cannot be understood without considering them in relation to each other. Besides the fact that these two themes constitute the nodal points of the work's argumentative structure, their originality and their impact ${ }^{23}$ alone justify an analysis of the Shifä"s doctrinal content for the history of Islamic ideas. Considering the way al-Qādî 'Iyād, as a major representative of both hadīth and theology in the Maghreb of the sixth/twelfth century, ${ }^{24}$ uses various Islamic genres and discourses, this study analyses how the author develops his argumentation in order to demonstrate the pre-eminent status of the Prophet and to argue the duty for Muslims to adopt an attitude of love and veneration for him.

the Person of Muhammad began to be dogmatised, see Nagel, "Tabuisierung", 482, and Wagner, "Problem of Non-Muslims", 531f.

21 See Fierro, "El tratado" and Iruela, Veneración.

22 In particular Andrae, Person Muhammeds; Schimmel, Und Muhammad; Nagel, Allahs Liebling; Khalidi, Images of Muhammad.

23 There is yet no specific study about the reception of the Shifä and of its themes, but even then, it can be safely assumed that the incredible success of the work is due, among other things, to his elaborating on the knowledge of the Prophet's status and on love for him. For the popularity and the diffusion of the Shifä, Kattānī, al-Madkhal ilā kitāb al-Shifä offers useful indications.

24 See in particular Turābī, Juhūduhu fì 'ilm al-ḥadīth; Shawwāț 'Ālim al-maghrib; Al-Abdallāh, Juhūduhu al-kalämiyya; Serrano, "Diffusion de l'ash'arisme"; Vimercati Sanseverino, "Transmission, ethos". 


\section{Knowledge of the Prophet's Pre-eminence}

It is clearly apparent for anyone who has any practice of science ('ilm) or has the slightest degree of understanding ( fahm) that God exalted the dignity of our Prophet (ta'zim Allāh qadr nabiyyinā), and that He singled him out with countless virtues, beautiful character traits and illustrious deeds, and that He acclaimed his exalted dignity with what the words and pens cannot express. ${ }^{25}$

At first sight, this introductory remark, which al-Qāḍ̄ 'Iyāẹ places at the beginning of the first part of the Shifä, does not represent anything unusual. The theme expressed in this passage constitutes a common topos in Islamic literature dealing with Muhammadan prophecy. In fact, the issue of the latter's authenticity, role and status is commonly approached in terms of the Prophet's pre-eminence, expressed through notions like "nobleness" (sharaf) or "favour" ( $f a d l)$. The pre-eminence of the Prophet Muhammad is presented as evidence of the authenticity of his prophetic mission and of the revelation he claimed to have received. It is the pre-eminence of the Prophet, his superiority towards the other prophets, his function as a seal of prophethood, but also his physical, moral and spiritual excellence, which give evidence of his claims to be a messenger from God. Furthermore, the discourse of pre-eminence is meant to demonstrate that Muhammadan prophethood constitutes the apogee of the history of salvation. Showing that Muhammad is the creature most beloved and esteemed by God aims to prove the superiority of the Prophet's religion over the other religions.

According to previous research, the early prophetological treatises articulating this conception were designed to respond to the contestation of Muhammad's prophetic status from other religions. ${ }^{26}$ However, this interpretation has since been considerably nuanced by Mareike Körtner in her study of the Daläil al-nubuwwa literature. She shows that these works were not merely polemical, i.e., intending to convince or defeat a theological opponent, but that it was constitutive for the formation of a distinct Sunnī identity. ${ }^{27}$ Now

\footnotetext{
25 'Iyād, Shifä̀, 19.

26 "Muhammad's claim to prophecy triggered a Jewish and Christian attack on his prophetic qualifications, which forced the Muslims to establish a system of vindication of Muhammad's prophecy. The existence of this system obliged the Christians to respond with 'the negative signs of true religion,' their own version of the 'signs of prophecy', this response in its turn influenced later Muslim depiction of Muhammad and of early Islamic history" (Stroumsa, "Signs of Prophecy", 101-14).

Koertner, Clear Signs.
} 
al-Qāḍi 'yyāḍ integrated the various prophetological genres and discourses, even those originally developed in an apologetical context, into a mainly intraMuslim one. As indicated in the passage quoted above, and as will become clear when analysing the topics and the argumentative structure of the Shif $\bar{a}$, he based his elaboration of the theme of Muhammad's pre-eminence on three interrelated postulates. The first was that the reality of Muhammad's status is wholly determined by God's will and work, the second, that God accorded to Muhammad the most eminent status amongst His creatures, and the third, that, in its divine determination, the reality of this status is beyond human comprehension and expression. The theme of Muhammad's pre-eminence no longer serves to argue and to demonstrate the authenticity and superiority of his prophetic claim against non-Muslims, but to disclose the soteriological meaning of Muhammad's prophetic status to those who believe in him and follow him. Thus, from this perspective, the pre-eminence of the Prophet is not merely the sign of his veracity, but of his unique relationship to God.

\subsection{The Notion of Qadr and the Issue of the Prophet's Status}

Al-Qādị̄ 'Iyāḍ's new approach is visible in his use of a distinctive term in order to address the theme of the Prophet's pre-eminence. The notions of $q a d r$ al-nabi ("the status, worth and dignity of the Prophet") and of 'azim qadrihi ("the immense and exalted reality of his dignity") refer to the Qur'annic term $q a d r^{28}$ as used in Q 65:3, "God gave to every thing its measure (qadr)", and in Q 39:67, "And they did not give God the measure/value ( $q a d r$ ) which is truly His". ${ }^{29}$ While the first reference identifies the $q a d r$ as the particular and divinely determined reality of a thing, the second reference relates the qadr to the quality of man's relationship to God. Without stating it explicitly, the term qadr applied to the Prophet suggests an analogy between the failure to recognise God's status as omnipotent Creator, and the negligence towards the Prophet's eminent status and dignity.

The use of the term qadr for Muhammad's status can equally be traced back to a hadīth that al-Qāḍi 'Iyāḍ mentions in the chapter relating narrations which attest to the Prophet's eminence: "It is narrated from Abū Muhammad al-Makkī, Abū al-Layth al-Sarmaqandī and others that Adam said when he disobeyed God: 'My God, by the right (bi-haqq) of Muhammad, forgive me

28 In his extensive commentary of the Shifă’, the Egyptian scholar Shihāb al-Dīn al-Khafājī (d. 1069/1659) explains this notion as follows: "The qadr of a thing is its measure (miqdār) and its nobleness (sharaf) and rang (rutba); it means the magnification (ta c $\left.^{\mathrm{i}} \mathrm{im}\right)$, as in God's word 'and they do not give God the measure that is His' (Q 39:67), i.e. they did not magnify God the magnification which is truly His" (Nasim, I, 92). 
my fault!' [...] and in another version: "God asked Adam: How do you know Muhammad?" and Adam answered: "When You created me, I raised my head to Your throne and I saw inscribed on it 'There is no divinity except God, Muhammad is His messenger' and I understood that there is nobody whose status is greater in Your sight (azam qadran 'indaka) than he whose name You associated to Yours [...]".30 The semantic field of the term qadr shows how it allows al-Qāḍi 'Iyāḍ to treat the soteriological significance of Muhammad's prophethood and its reality as determined by God, as well as to emphasise the practical and normative meaning of the Prophet's pre-eminence. In this way, the recognition of the Prophet's qadr becomes constitutive for Islamic faith and is shown to determine the quality of a Muslim's relationship to the person of the Prophet.

If the aim of the first part of the Shif $\bar{a}$ ' consists in the knowledge of the Prophet's qadr, the question arises how his qadr can be known? This is indeed theologically important, since it determines how the relation between revealed and human knowledge on the Prophet can be conceived. Al-Qāḍī Iyād answers this question through the structure of this part. Its title "The exaltation $\left(t^{\prime} z i m\right)$ of the Chosen Prophet's dignity with God the Most High through word (qawlan) and deed (filan)"31 expresses the idea that the Prophet's status is exalted and thus not comparable to the status of any other creature, but also that this exaltation is caused and carried out by God Himself. ${ }^{32}$ In other words, the exalted status of the Muhammadan person is rooted in nothing other than God's creative action and grace. The titles of the four chapters of this part further indicate explicitly that the Prophet's $q a d r$ is made known and disclosed by God. In order to be apprehended and known by mankind, the exalted and immense reality of the Prophet's status needs to be made manifest through God's manifestation ( $i z h \bar{a} r)$, in order to become intelligible for human understanding.

30 'Iyāḍ, Shifä', 112. The earliest source for this hadīth is al-Hākim al-Nisabūrī, (m. 405/1014) al-Mustadrak 'alä al-Ṣahịhayn, kitab al-tafsìr, $\mathrm{N}^{\circ} 3042$. For the various sources of this hadīth and the controversy it gave rise, see Ibn al-Alawī, Mafāhim, 129. As we will see later, this understanding of the term of qadr is further confirmed by al-Qāḍī 'Iyāḍ's use of the term of haqq/huqūq (rights), which is also mentioned in this haditth, but for which he probably was inspired by al-Muhāsibī's work on Sufism, al-Ri'āya li-ḥuqūq Allāh (The observance of the rights of God).

31 'Iyāẹ, Shifä', 19. See also, 16, where the author explains how he has structured the Shifä'.

32 Al-Khafājī explains that "the magnifications of God indicate the nearness (qurb) of the Prophet to Him and that who loves Him, has to make [the Prophet] his utmost concern as if the Prophet was always with God" (Nasim, I, 92). 
This way of presenting the evidence of the Prophet's status is consistent with the Ash'arī conception of prophecy as a divine gift. ${ }^{33}$ However, al-Qāḍī 'Iyāḍ in fact thinks through the Ash'ari approach to prophethood to its end, and at the same time establishes in this way the theological basis of the Prophet's preeminence as well as of the practice of his veneration. Considering prophecy as a divine gift, and thus as the result of God's work of grace and not of man's moral or intellectual excellence, has precise consequences for the possibility of prophetological knowledge: if the reality of prophethood has a supra-human cause and reason, it cannot be explained in purely human or naturalistic terms, and therefore it is necessarily beyond human understanding. This entails the incapacity of the human mind to grasp the reality of the Prophet's status on its own. Mankind is in need of a divine communication as the only effective and truthful source for the knowledge of the reality of Muhammad's qadr.

This conception of the reality of prophethood in general, and of Muhammad's prophetic dignity in particular, is further buttressed by the use of the adjective 'azim in order to qualify the qadr and the manzila of the Prophet Muhammad. ${ }^{34}$ Firstly, because 'azim is considered to be one of God's 99 "most beautiful names". ${ }^{35}$ Secondly, because it is equally an attribute of the Qurân, that is, the divine word. ${ }^{36}$ And thirdly, because 'azim is associated in the Qur'ān with the inner nature, the khuluq, of the Prophet Muhammad. ${ }^{37}$ The concept of 'azim then, denoting the idea of immensity and applied theologically to the incommensurability between the transcendent and the contingent, symbolises a commonality between God, the revelation and the Prophet. ${ }^{38}$ It is what they have in common, so to speak, even if the "Creator's essence, names, acts and attributes" have nothing in common with those of created beings except for the

33 See Gardet, Théologie Musulmane, 179-80; Rahman, Prophecy, 96.

34 'Iyād, Shifä', 19, 21, and in particular 145 of the chapter "Concerning the God's ennobling him with names from His own beautiful names and His qualifying him with His own attributes" where the author explains that "the meaning of 'azim is attributed to the one whose affair is elevated above everything else and God says 'You are truly of an exalted character (khuluq 'azìm; Q 68:4)'”.

35 See for example Q 2:225 and Gimaret, Noms divins, 208-10. According to Gimaret, "that which no intelligence can grasp is the al-Azim al-muțlaq, God" (209).

$3^{6}$ See Q 15:87. The Study Quran, 652, translates "And We have indeed given thee the seven oft-repeated, and the Mighty Quran (al-Qur'ān al-'až̀m)".

37 Q 68:4. The hadith tradition confirms the characterisation of Muhammad's prophetic personality with the Qurānic revelation, for example in the hadìth 'His character was the Qurān' (Muslim, al-Ṣahīh, Kitāa șalāt al-musāfirīn, bābjām ‘ṣalāt al-layl, $\mathrm{N}^{\circ}$ 746.). See especially Gril, "Corps du Prophète".

38 On this point, see also the considerations by Gril concerning "L'homme révélé" in "Révelation et inspiration", 755 . 
correspondence of appellation (minjihatmuwäfaqat al-lafz al-lafz)". ${ }^{39}$ It seems that it is this "correspondence" which al-Qāḍi ' Iyāḍ wants to stress by using the term 'azim in this context. And in fact, he uses it very often in various forms, the most frequent variation being the factitive form $t a{ }^{\prime} z \bar{l}$, "God's rendering the Prophet "azim". ${ }^{40}$ The idea that God bestows certain effects or meanings of a divine attribute to the Prophet evidently has important consequences for the significance of the Muhammadan person for the community of the believers. It seems as if the author of the Shifä' insinuates that the believer has to consider the Prophet's significance for his salvation in an analogous manner to the significance of his faith in the Qurān and in God.41

If the reality of Muhammad's prophetic dignity, and consequently the scope and nature of his pre-eminence, are not graspable by the human mind, the question remains: how can mankind obtain knowledge of them? In the following passage, the author of the Shif $\bar{a}^{\prime}$ answers this question by distinguishing between the two categories of sources for the knowledge of the Prophet's pre-eminence: "Amongst [the favours that God bestowed on the Prophet] are those which God enunciates explicitly (șarraha) in His book [...] and those which He made manifest (abraza) to the eyes". ${ }^{42}$ Considering the chapters of the first part, it appears that the divine word corresponds to the revelation of the Quraan, and that divine action is represented by the creation ${ }^{43}$ of the Prophet's miracles (mujizät), character traits (mahāsin khuluqan) and appearances (khalqan), these three latter categories corresponding to evidence which is empirically perceivable. The third chapter on "What is mentioned in sound and well-known reports (șahịh al-akhbār wa-mashhürihā)" equally belongs to this category, ${ }^{44}$ in the sense that the hadiths are understood to be textual testimonies of the sunna which, according to the Sunnī tradition to which al-Qādī

39 'Iyāẹ, Shifā̄e 148. Al-Qāḍ̄ī 'Iyāḍ quotes here the Sufi and theologian Muhammad b. Mūsā Abū Bakr al-Wāsițī (d. ca. 320/923) who was a follower of Junayd al-Baghdādī and specialised in this theme. See Silvers, Soaring Minaret.

40 This expression actually figures in the title of the first part, see 'Iyād, Shif $\bar{a}$ ', 19. There is also a long chapter in al-Bayhaqì's (d. 458/1066) famous hadīth compilation Shu'ab al-ïmān, II, 193-234, with the title ta'zim al-nabi, constituting "the fifteenth branch of faith".

41 This goes even so far that al-Qāọī 'Tyād deemed it necessary to add a subchapter about the incomparability between creator and Creator, even if no Muslim scholar would rank any being next to God, nor to God's word, see 'Iyād, Shifä’, 148-49.

42 'Iyāḍ, Shifä' p. 19.

43 Al-Qādī 'Iyāạ uses the terms iz̧ā̄r (making manifest) for miracles and takmīl (making perfect) for the Prophet's characters and appearance. In both cases, God is the sole agent. 'Iyāḍ, Shifä', 107-49. 
'Iyād counted himself, has the status of revelation (wahy $)^{45}$ and therefore is the result of divine agency. ${ }^{46}$ At the same time, these reports belong to "empirical" evidence in the sense that they claim to be based on visual or auditive testimonies. The same holds for the topics of the two other chapters, i.e., the Prophet's miracles and his personality, since these are manifested in history and knowable as historically transmitted reports $(a k h b \bar{a} r) .{ }^{47}$

It is clear that the perspective on which these considerations are grounded presupposes a theological and occasionalist conception of history. This is not surprising, since such a conception is inherent to the hadith tradition and to the dynamics of its transmission. As Abdallah Laroui points out, the hadith constitutes a form of historical writing and conveys a theological conception of history, with "specific understandings of continuity, time, event, finality, etc.". ${ }^{8}$ In this way, "history appears as a perfect unity, where the origin and the end, the promise and the accomplishment coincide". ${ }^{9}$ Hence, "the origin and the end of history are known, the sense of each event is already given, the historical account is, in its whole, merely a metaphor that the chronicler registers and the theologian interprets".$^{50}$ So even if the author does not use the term "history", it is clear that these three chapters, dealing with evidence "which He made manifest to the eyes", concern evidence from history if the latter is defined in theological terms as salvation history or as the working of God in human history. As al-Qāḍi 'Iyāḍ is never tired to repeat, the events and qualities mentioned in these chapters are created by God and have their origin in His acts.

To resume this significant point, the structure of the first part shows how the Shif $\ddot{a}$ argues that the two sources for knowledge of the Prophet's reality are revelation and salvation history, corresponding respectively to God's word and

45 However, it seems that the Qurān and the sunna belong to two different categories, the first being in reality a purely scriptural revelation the scriptural form of which is part of the divine revelation itself, whereas the sunna is revelation through God's inspiration of the Prophet's words, acts and consents, so not scriptural in the strict sense. This would explain why the third chapter does not belong to the category of evidence from the divine word, but to the category of evidence from divine acts.

46 For al-Qāḍī 'Iyāậs elaboration on this point, see Vimercati Sanseverino, "Transmission, ethos".

47 Al-Khafājī interprets this passage in very similar sense, but includes the hadìth qudsī to the first category, see Nasim, I, 114-15.

48 Islam et Histoire, 38 , see also Nagel, "Vernichtung der Geschichte".

49 Laroui, Islam et Histoire, 94.

50 Laroui, Islam et Histoire, 94-95. On the role of hadith for the origin of historical writing, see Khalidi, Historical thought, $17-83$. 
to His acts. As a consequence, the thematical and argumentative structure of the first part of the Shifä' represents the following scheme:

TABLE 5.1 Sources for the knowledge of the Prophet's reality in the first part of the Shifā'

Part I: God making manifest the Prophet's pre-eminence ...

- through word (qawlan) - ch. 1: Qurānic evidence

- and act (filan)

- ch. 2: evidence from the Prophet's appearance and character traits

- ch. 3: evidence from testimonies regarding his pre-eminence

- ch. 4: evidence from his miracles

\} revelation salvation history

\subsection{God's Word and Revelation}

Looking now more closely at the first chapter, "Regarding God's praise of him (the Prophet) and His making manifest the Prophet's exalted status with Him (izhārihi 'azìm qadrihi ladayhi)", ${ }^{51}$ the word izhārihi requires special attention. Expressing the idea that it is God who makes the eminent dignity of the Prophet evident and manifest, it can be considered the hermeneutical key of the Qurānic exegesis that al-Qāḍi 'Iyād develops in the Shifä̀. In fact, he is not the first who expounds the idea that God reveals in the Qur'ann the eminent dignity of the Prophet Muhammad. For example, in Kharkūshīs (d. 406/1015) Sharaf al-Mustafa a there is a whole section about "The nobleness of the Prophet according to the Qurānn". ${ }^{52}$ And Abū Nu'aym al-Iṣbahānī (d. 430/1039) begins his Daläil al-nubuwwa with a chapter titled "What God revealed in his book about the Prophet's precedence (fadlihi)", that is, the favour bestowed on him by God. ${ }^{53}$ This idea has also been expressed in other genres. Shāfíi speaks in his famous Risāla about "God's clarification of the station in which He put His Emissary" in order to argue the soteriological and therefore normative meaning of the prophetic Sunna. ${ }^{54}$ Further, the idea that the Qurān unveils the

$5^{1} \quad$ Tyāḍ, Shifä̀, 21.

$5^{2}$ Kharkūshī, Sharaf al-Muștafā, IV, 93-19o.

53 Abū Nu'aym al-Iṣbahānī, Dalāill al-nubuwwa, 39-56.

54 Lowry, Epistle on legal theory, 27, 63. This important work is an example illustrating how prophetological themes elaborated in the Shifä’ are in fact already present in various Islamic discourses: "God has rescued us from demise through [the Prophet Muhammad] and placed us in 'the best community brought forth for the people' (Q 3:110), adherents of His religion, the religion of which He approved and for which He elected His angels and those of His creatures whom He graced. No act of grace has touched us - whether 
Prophet's reality reminds one of Sahl al-Tustari's Sufi exegesis of the prophetic light, ${ }^{55}$ which al-Qāḍī 'Iyāḍ cites at some places in the Shifẳ. ${ }^{56}$

What distinguished al-Qāḍi 'Iyāḍ is that he makes this idea, namely that the Qur'ān expounds the Prophet's exalted status, the very foundation of his prophetology in both its doctrinal and practical dimensions. Accordingly, the purpose of revelation and meaning of God's speaking to mankind is not limited to the proclamation of divine attributes and commands, but equally includes the disclosure of the Prophet's status (qadr), and of his "rights" (huqūq). As the Qur'ān presents itself as guidance $(h u d \bar{a}),{ }^{57}$ this means that for al-Qādî̀ 'Iyād this prophetological knowledge is part of divine guidance and therefore belongs to those essential issues that humanity needs to know for the attainment of salvation. In other words, the knowledge of the Prophet's exalted status is part of the Qurannic message and therefore of God's ultimate message to mankind.

The Qurānic evidence that al-Qāḍī 'Iyāḍ presents about Muhammad's exalted status is manifold. It concerns the event of revelation as an act of divine communication itself, as well as the content of this communication and its linguistic form and style. Regarding the first aspect, the event of revelation, al-Qāḍi 'Iyāḍ treats it mostly in the chapter on the Qurānic miracle (ijjāz al-Qur'ān) which we will discuss below when treating the chapter on miracles. In this first chapter, though, the focus is largely on how God addresses Himself to the Prophet and how He speaks about him. So, we are told how the Qurān does in fact involve God's praise (al-thana $)$ of the Prophet Muhammad. When God qualifies him as the instrument of His mercy $(\mathrm{rahma})^{58}$ and favour, when He names him "light" and "a lamp spreading light",59 etc. He does so in order to unveil the exalted dignity and the pre-eminence of the Prophet. In the third

outwardly or inwardly, and through which we attain benefit in religion and this world or have averted from us what is evil in one or both of them - of which Muhammad was not the cause, the leader to its blessing, the guide to its proper route, the one who protects us from perdition [...]" (Lowry, Epistle on Legal Theory, 9).

55 Böwering, Mystical Vision, 149-153, and Keeler, Tafsìr, xxx-xxxiii. The influence of al-Tustarì's exegesis on the Shifä has already been noted by Böwering, Mystical Vision, 37, 65-66, 157-158, 16o-161.

56 See for example Shifä, 23. Tustarī is also quoted regularly in other contexts, for example with regard to the spiritual meaning of the $i t t i b \bar{a}^{c}(S h i f \bar{a}, 226,230,232)$. According to his son (Ta'rî̃, 42), he even received an isnād of Tustarī's sayings through Abū 'Alī al-Ṣadafī (d. 514/1120), one of his most important teachers in ḥadīth (see Shawwāt, Álim al-Maghrib, 76-78; Turābī, Juhüduhu fì ilm al- hadìth, 126-132).

57 See for example Q 2:2.

$5^{8}$ 'Iyāọ, Shifä', 22.

59 'Iyāẹ, Shifä', 23. 
sub-chapter, for example, "What God's speech (khitāab) to him contains of tender treatment (mulätafa) and benevolence (mabarra)", ${ }^{60}$ the author makes use of classical exegetical resources in order to bring out the singular delicacy of God's dealing with the Prophet, even when rebuking him.

Considering the various themes of the first chapter, including Qurannic oaths, ${ }^{61}$ the allusions to the Prophet's role as a witness of mankind, ${ }^{62}$ to his rank amongst the prophets, ${ }^{63}$ or to his divine protection and the protection from divine punishment through him, ${ }^{64}$ there appears a vision of the Qurān which presents it as an intimate dialogue between God and His most beloved creature. Al-Qāḍi 'Iyāḍ visibly seeks to make evident the intimacy that characterises the relationship between God and his Prophet as it appears in the Qur'annic text. For the author of the Shifä), this shows the Prophet's nearness to God, expressed in a privileged and unique relationship that characterises him in an exclusive way so that no other creature enjoys a comparable relationship with Him.

This opens a distinctive prophetological hermeneutics of the Qur'ānic text which had not been developed systematically. ${ }^{65} \mathrm{He}$ invites the reader to read the Qurân along this line and argues that, in this way, the Qur'ān becomes the principal source of knowledge of the Prophet's reality. As his usual fashion, the author insists that this has quite practical implications for the reader: "It is incumbent upon every Muslim who struggles against his lower soul and whose character is restrained by the bridles of sacred law that he educates himself through the education of the Qur'àn (adab al-Qur'ān) in all his words, acts, endeavours and engagements, because it is the archetype of truthful insights and the garden of worldly and religious education".66

6o 'Tyāḍ, Shifä', 29-31.

61 'Iyād, Shifä', 31-36.

62 'Iyād, Shifä', 26-29.

63 'Iyād, Shifä', 37-39.

64 'Iyād, Shifä', 39-40.

65 As already mentioned, it is obvious that al-Qāḍī 'Iyāḍ took up certain chapters from the Dalāil al-nubuwwa literature, in particular from al-Ișbahānī, Dalāil al-nubuwwa, 39-48, which shows strong similarities with the Shifä' in this respect, and the chapter on "The nobleness of the Prophet in the Qur'ān" of Kharkūshī, Sharaf al-Muștafā IV, p. 93-179, which develops both aspects mentioned above through the description of the Prophet's singularity, and God's oaths on him (IV, p. 180-185). However, on these themes, the Shifä' appears to be much more elaborate than previous works.

'Iyāḍ, Shifā', 29-30. 


\subsection{God's Acts and Salvation History}

Turning now to the second category of evidence for the Prophet's preeminence, i.e. the signs "which God made manifest (abraza) to the eyes", ${ }^{67}$ the question of how God's acts on the Prophet, as manifested in salvation history, are to be considered as sources of prophetological knowledge, is most obvious in the case of the prophetic miracles $(a l-m u j i z a \bar{t}) .{ }^{68} \mathrm{Al}$-Qāḍi 'Iyād devotes a very long chapter of Part 1 to this topic, with the title "Concerning the miracles which God made appear through his [i.e. the Prophet's] hands, and the singularities and favours through which He honoured him". ${ }^{69}$ As explained by Daniel Gimaret, in Ash'arī theology, the "miracle has the purpose of attesting the veracity $(s i d q)$ of the one in whom it is manifested" 70 so that miracles are considered to be proofs of the authenticity of prophecy. However, the probative force of miracles has been put into question by philosophers and theologians alike. ${ }^{71} \mathrm{Al}-\mathrm{Q} a \bar{d} \mathbf{i}$ 'Iyāẹ apparently sticks to the usual Ash'arī concept as a doctrinal position. In the introductory section dealing with the meaning of prophecy, revelation and miracle, he explains that "the miracle along with the challenge [to the deniers of Muhammad's prophecy] (tahadd $\bar{\imath}$ ) takes the place of God's statement "my servant has said the truth, so be obedient to him, follow him and attest to his veracity in what he says". ${ }^{72}$

At the same time, the author seems to admit the relativity of the probative force of miracles when he states:

What we have presented of the Prophet's beautiful qualities, of testimonies of his state, the truthfulness of his sayings [...] has been enough for more than one for his submission (islämihi) and faith in him. We have narrated from Tirmidhī and Ibn Qānic and others through their lines of transmission, that 'Abdallāh Ibn Salām ${ }^{73}$ (d. 43/663), when he entered

67 'Tyāẹ, Shifä', 19.

68 Al-Q̨āịi 'Tyāọ elaborates a precise definition of this term as "that what a creature is incapable of performing", either "because of God's act disabling them (tajizuhum 'anhu fil li-llāh)" or because "its being beyond human capacities (khärij 'an qudratihim)" (Shifä, 153).

69 'Iyāạ, Shifä', 150-224.

70 Gimaret, Ash'arī, 461-462.

71 See Gardet, Théologie musulmane, 197-201. Ibn Rushd and even scholars like Ibn Taymiyya criticised the theologians' claim that Muhammad's miracles prove his prophethood. Even Ghazāli differed on this point from early Ash'arīs. On "Prophetical Miracles and the Unchanging Nature of God's Habit" in Ghazali's thought and its reception, see Griffel, Philosophical Theology, 194-201.

72 'Iyāḍ, Shifä', 152.

73 A known Rabbi of Medina who converted to Islam. 
Medina, reported that "I came to him in order to see him and when his face appeared clearly to me, I knew that his face cannot be the face of a liar. ${ }^{74}$

A little further on, al-Qādị̂ 'Iyāẹ cites an interpretation of a passage from the Qur'ānic light verse: "Its oil would almost glow forth, though no fire touched it" (Q 24:35). He states that "this is a parable set by God for His Prophet meaning that his sole sight (manzaruhu) would indicate his prophethood without the Qur'ān having been recited by him, as Ibn Rawāha (d. 8/629) ${ }^{75}$ declaimed: 'Even if he had not possessed clear signs, his mere sight had proclaimed the message"." ${ }^{76}$ Rather than the miracles in themselves, it is God's working of grace on the personality of Muhammad which constitutes the most manifest evidence of his prophetic dignity. ${ }^{77}$

In light of the fact that, as stated before, the Shif $\ddot{a}$ ' was written for Muslims, it becomes clear that the chapter on miracles has no apologetical or polemical purpose, but an edificatory one. Miracles are integrated into the discourse about the Prophet Muhammad's pre-eminence. The probative value of the miracles is not the real subject here. The function of the miraculous powers that God granted to His Prophet is to unveil the latter's eminence, his 'azim qadr. From this perspective, miracles are essentially palpable signs of the Prophet's nearness to God and of the privileged relationship the Prophet enjoys with the Creator of mankind. ${ }^{78}$

74 'Iyāḍ, Shifä', 15 o.

75 A Companion from Medina and secretary of the Prophet, known for his poetry.

76 'Iyāḍ, Shifä̀) 151.

77 It is interesting that al-Qāọī 'Iyāọ did not refer to Ghazāli’s doctrine. As Frank Griffel explains, "in his autobiography, for instance, al-Ghazālī says that the experience (tajriba) of the positive effects of a prophet's work on one's soul generates necessary knowledge ( 'ilm darūri $\bar{l}$ ) of his prophecy. In this case, the judgment of experience is established by the repeated concomitance between performing the Prophet's ritual prescriptions and the positive effects this practice has on one's soul. That resulting judgment, namely, that Muhammad can effectively heal the soul through his revelation, establishes certainty about prophecy (yaqin bi-l-nubuwwa) and results in belief that equals the power of knowledge (al-ìmān al-qawī al-ilmì)" (Philosophical Theology, 208).

78 It is possible that the author of the Shifa ${ }^{\prime}$ in fact develops here the idea already present in Iṣbahānī's "Evidences of prophecy" that miracles indicate the Prophet's status and position with God: "God almighty supported Muhammad with what he had not supported any one of the two worlds, and He distinguished him with what surpassed the boundaries of the miracles of the prophets and the stations of the saints for the signs of prophecy are in accordance with his [i.e. the prophet's] station and position with God. There is no sign $(\bar{a} y a)$ and no indicator ('aläma) more exceptional and more marvellous than the signs 
While the various sub-chapters treat the different categories of prophetic miracles which can be found in previous Daläil al-nubuwwa works, the i ijäz $a l$-Qur'ān ${ }^{79}$ is presented as the most significant miracle and thus the most evident indication of the Prophet's pre-eminence. ${ }^{80}$ But unlike in the first chapter, it is not the content of the Quran which is taken here as evidence of the Prophet's pre-eminence, but the very fact of its revelation to him. The ijjaz applies principally to the Qur'ān's language, composition and content, ${ }^{81}$ but also to the impact that the Quràn continues to exercise on both those who contest it and those who believe in it. Whereas the first are faced with the impossibility of profaning it and continue to be affected by perplexity when listening to it, ${ }^{82}$ the believers continue to experience the "sweetness of its recitation" without ever getting annoyed by it. ${ }^{83}$ In the argumentative framework of the Shifä', the miraculous character of the Qurān and its singularity amongst revealed scriptures is evidence for the pre-eminence of its receiver and transmitter, that is the Prophet Muhammad. An interesting aspect of this argument is the continuing actuality of this miracle which is stressed by the author, ${ }^{84}$ as it indicates that the miraculous character of the Qurān remains a source for prophetological knowledge even after the Prophet's death. It is, so to say, evidence that never ceases to speak of the Prophet's pre-eminence to the believers, in any time and place.

In the third chapter on evidence from the hadith, the topics treated are the Prophet's election, his night journey and ascension (al-isrä's wa al-mi'räj), his

of Muhammad, and that is the eloquent Qur'an [...]" (Iṣbahānī, Dalā'il, 134, translated by Körtner, Clear Signs, 213).

79 It is possible that he based himself on Baqillān’’s (d. 403/1013) famous Ijjāz al-Qur'ān treatise. However, even if there is a preponderance of the rhetorical aspect of the $i^{i} j \bar{a} z$, al-Qādī 'Iyāḍ refers to the various aforementioned conceptions of it (see Kermani, Ästhetische Erleben, 247).

8o On the i $i j \bar{a} z$ al-Qur'ān as evidence of the authenticity of Muhammad's mission, see Gardet, Théologie musulmane, 218-21.

81 'Iyād, Shifä', distinguishes two aspects of this topic, the unveiling of unknown things (al-mughayyabāt) (162), and the information about past events and scriptures etc. (162ff.).

82 'Iyāọ, Shifä', $164 \mathrm{ff}$.

83 'Iyād, Shifä', 166-67. In the following pages, other examples of the i ijäz are discussed, such as the facility to learn the Qurān by heart, the unparalleled force of its argumentation etc.

84 He speaks for example of the fact that the Qurān "constitutes a sign which subsists and never ceases to be as long as this world subsists, in virtue of the guarantee of God's preservation" (Shifä) 166). Of course, there is nothing unusual in mentioning this aspect, but it acquires a new significance within the prophetological framework of the Shif $\bar{a}$, as explained in the remark that follows. 
eschatological pre-eminence, ${ }^{85}$ his superiority vis-à-vis the other prophets, and the favours attached to his names, in particular through their relation to God's attributes. ${ }^{86}$ The section dedicated to the night journey and ascension occupies the most space. ${ }^{87}$ It has an evident interreligious significance for, amongst other things, Muhammad's night journey involves the demonstration of his role as leader and chief of the prophets in Jerusalem. Moreover, the author discusses at length the controversial questions of whether the Prophet undertook the ascension with his body and in the state of wakefulness, ${ }^{88}$ both of which affirmed, taking thereby a markedly traditionalist stance within the theological discussions. Al-Qāḍi 'Iyāḍ equally dedicates a whole sub-chapter to Muhammad's vision (ru'ya) of God, ${ }^{89}$ to their conversation (munājāt $)^{90}$ and to his extreme rapprochement (al-dunuww) to Him. ${ }^{91}$ While mentioning, in his usual fashion, the different opinions on these issues, the author of the Shifa $\bar{a}$ himself argues that reason and scripture establish that the Prophet saw his Lord, that he conversed with Him without any intermediary, and that he was in proximity to God as no other creature before or after him:

In truth, the extreme rapprochement (dunuww) has no limit and the rapprochement of the Prophet to his Lord and his proximity to Him is a clear elucidation of his exalted status and of the ennoblement of his rang, as well as of the shining [on him] of the lights of knowledge of God and of the vision of the secrets of His incommensurability and power; from God this [rapprochement] means benevolence, intimacy, generosity and honouring $\left[\ldots . .{ }^{92}\right.$

In last analysis, the Prophet's vision of God marks his singular status amongst mankind, since this favour has not been accorded to anyone before him: "Of every sign that prophets have received, our Prophet has received its equivalent

85 'Iyād, Shifä', 128-39. This topic, which is beyond our scope here, has a major importance for the argument of the Shifä.

86 'Tyāọ, Shifä', 144-48.

87 Al-Qāḍi 'Tyāḍ engages in a lengthy discussion about the variant narrations of this event. For a study of the sources of the narration and their reception, see Colby, Narrating Muhammad's Night Journey.

88 Shifä', 120-22.

89 Shifä', 122-26. On this issue in particular, see Van Ess, "Mi'rāj".

90 'Iyāạ, Shifä', 126.

91 'Iyād, Shifä', 127-28.

92 'Iyāḍ, Shifä', 127. 
and he is distinguished amongst them through the favour of the direct vision [of God]".93

Considering the place conceded to both themes, revelation and ascension appear, amongst the evidence accessible through testimonies in history, as the most valuable signs allowing knowledge of the Prophet Muhammad's qadr. It seems that, for the author of the Shifäa, the descent of God's word and the ascension to His proximity make God's work on the Muhammadan personality visible in the most manifest and effective manner. ${ }^{94}$

\section{3}

\section{Love for the Prophet}

Besides the exegetical and theological elaboration of a prophetology based on the notion of $q a d r$, the second particularity of the Shifä consists in the exposition of the meaning of the Prophet's eminence for the religious life of the believers through the notion of haqq/huqūq figuring in the title of the book. The eminent status of the Muhammad's prophetic personality requires the adoption of a certain attitude and behaviour towards him. In other words, it requires the fulfilment of the duties defined by the "rights (huqūq) of the Prophet" such as faith (immann) in him, obedience (țāa) to him, taking him as orientation (ittib $\bar{a}$ ), veneration and respect (tawqir) of the sacred character (hurma) of his person, praying for him, visiting his grave, and respecting people associated with him, such as the members of his family and his descendants.

Amongst these rights, the haqq which demands love for him (mahabba) represents one of the core elements of the Shif $\bar{a}$. As we have seen, the author indicated that the strengthening of the Muslim community's love for the Prophet Muhammad constituted the principal purpose of writing the Shifä. It is therefore not surprising that the chapter on love represents perhaps the most elaborated one among those dealing with the Prophet's rights. Concerned with the substantial driving force and the fulfilment of the believer's relationship to the Prophet, it is situated in the middle of the book and thematically binds together the different parts while representing their topical climax. Indeed, al-Qāộ̄ 'Tyāḍ himself emphasises the pivotal significance of love by arguing that the fulfilment of the other rights results from it:

93 'Iyād, Shifä', 124. The statement is attributed by the author to Ahmad Ibn Hanbal.

94 In both cases, one can indeed speak of a "transfiguration" of the prophetic personality, see Gril, "Corps du Prophète", 49, who speaks of "consummation" and Van Ess, "Mi'rāj", 29-3o, who prefers to speak of "glorification". 
Know that whoever loves anything, gives preference to it and prefers to conform to it; otherwise he is not sincere in his love and is just pretending. He who is sincere in his love for the Prophet, its sign ('aläma) will appear on him. The first sign consists in his taking [the Prophet] as a model, applying his Sunna, following him in his words and acts, complying with his orders and shunning the things he prohibited, observing his way of behaviour ( $a d a b)$ in hardship and relief, in adversity and prosperity. The witness of this is God's word: "Say: If you love God follow me and God will love you" (Q 3:31).95

\section{1}

\section{The Prophet's “Rights" (ḥuqūq al-nab̄) and the Love That Is Due to Him}

Despite the very obvious originality of the concept of huqūq al-nabī, there is no discussion in research about this notion or about this part of the Shifä. ${ }^{96}$ Al-Qādị 'Iyāḍ himself does not offer any explication; he simply develops what these $h u q \bar{u} q$ are and what they imply for the religious life of Muslims. However, the relevance of the theme is rhetorically justified in the introduction through the demand of an unknown person to write a compilation including the definition of what the Prophet Muhammad "is entitled to (mä yajibu lahu) as regards respect (tawqï) and honouring (ikrām)". ${ }^{97}$ Furthermore, in the hadith already mentioned in which Adam supplicates God after the expulsion from paradise, the notion of haqq Muhammad is already present. Although here it does not explicitly refer to the relationship of the believers to the Prophet, but is rather to be understood in the sense of the Prophet's "reality" and the singular consideration that God has for him. In any case, the narration shows the relation between the concept of $q a d r$, which is more directly alluded to in the hadith, and the concept of huqūq: Both ensue from the consideration that God has for the Prophet Muhammad. The use of the term haqq in the sense of "right" is further supported by its use in the hadith literature. ${ }^{98}$ Probably even more significant is the fact that al-Qāḍī 'Iyāḍ quotes a passage from the Qurānic exegesis

\footnotetext{
95 Shifäa, 235 .

96 In Vimercati Sanseverino, „Wer dem Gesandten gehorcht“, 70-73, a few aspects of this notion with regard to the theme of the Prophet Muhammad as God's mercy have been discussed.

97 'Iyāẹ, Shifä', 13.

98 For example, in the Sunan of Tirmidhī, one can find sub-chapters on haqq al-wālidayn ("the right of the parents") and on haqq al-jiwār ("the right of the neighbour") in the Abwāb al-birr wa al-șila (25).
} 
of the Sufi and hadīth scholar Abū 'Abd al-Rahmān al-Sulamī (d. 412/1021) with the expression "the negligence of his [the Prophet's] right (ihmāl haqqihi)". ${ }^{99}$

As Anver Emon explains, the term haqq (pl. huqūq) has a complex meaning in Islamic thought: "Among the definitions advanced by premodern lexicographers, one is that the term haqq refers to something incumbent upon one to do (haqq 'alayya an af'ala dhälik). [...] The term haqq signifies both an obligation on one person and a claim of right on another."100 As for the "rights of God" and the "rights of individuals", these "constitute a legal heuristic that jurists used to ensure that the shari'a as a rule of law system upholds and, when necessary, balances both society's needs (i.e. the social good) and private interests." ${ }^{\prime 101}$ However, the legal meaning of huqūq is probably less significant for al-Qāḍi 'Iyādẹ's notion of the Prophet's rights, even if the last chapter of the Shifä' and the issue of blasphemy seems to have some relevance to the relation between the private and public dimensions of socioreligious taboos. The huqūq al-nabi rather remind of al-Muhāsibīs (d. 243/857) concept of hauqūq Allāh which he expounded in his famous treatise al-Ricāya li-huqūq Allāh ("The observance of the rights of God"). The text was widely read in the circles frequented by

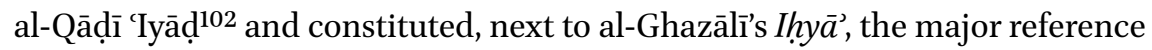
of spiritual practice in the Maghreb of the sixth/twelfth century. ${ }^{103}$ The originality of the work resides in the fact that al-Muhāsibì establishes the concept of the huqūq of God as a key concept of Islamic spirituality:

What concerns the question of the rights (huqūq) of God, know that this is an enormously important matter which is neglected by most men of our time. For God has taken His prophets and saints into custody because of this matter, as they respected His covenant and obeyed His commands. [...] So God has ordered His servants to respect and fulfil every right (haqq) He imposed on them, whether it concerns themselves or their fellow human beings. [...] God has made the respect of these rights the key for blessing in this and in the other world [...], so all creatures are bound

99 'Iyāḍ, Shifä', 242.

100 Emon, "Huqūq Allāh".

101 Emon, "Ḥuqūq Allāh", 327.

102 The author of the Shifä has studied the work of Muhāsibì with the Andalusian Sufi Muhammad Ibn Khamīs Abū 'Abdallāh al-Sūfī, amongst others, as he mentions in his intellectual auto-biography, remarking that "I used to sit with him very often" (alGhunya, 92).

103 See Vimercati Sanseverino, Fès et sainteté, 535-537. According to Casewit (Mytics of Andalus, 32), the Ricaya was introduced in al-Andalus by the theologian and poet Ahmad al-Ilbīrī (d. 429/1037). See also Vizcaino, Obras de zuhd, 427. 
to know the rights of God, with all their requirements, moments, purposes, duties and their order. ${ }^{104}$

By putting the notion of huqūq at the centre of religious life, Muhāsibī identifies it as a core issue of prophetic missions and of the history of salvation. The diagnosis that these rights were neglected by his contemporaries led Muhāsibī to write a book on this theme. Moreover, the passage shows clearly how he transposes this notion into the domain of spiritual practice and thus makes evident the correlation between spirituality and normativity. Al-Qāḍi 'Iyāḍ's use of the term of huqūq and its application to the Prophet ${ }^{105}$ is to be understood in the same line. It implies that the rights of the Prophet belong to those duties which God asks His servants to fulfil and which have been neglected by the contemporary Muslim community.

This sheds some light on the somewhat unexpected idea that love for the Prophet constitutes a "right". The implicit analogy between love for God and for the Prophet is certainly voluntary. It is based on the idea that man's relationship to God cannot be considered independently from his relation to the Prophet; the quality of the first is conditioned by the quality of the latter. This is so, because God has established the Prophet as the intermediary and mediator between mankind and Himself,106 a fact which, according to al-Qāḍī 'Iyāḍ's line of argumentation, is demonstrated by the eminence that God accorded to the Prophet Muhammad.

Al-Qāọī 'Iyād corroborates his elaboration on the normative character of the love for the Prophet Muhammad with scriptural evidence that is usually related to the theme. Of course, the theme of love for the Prophet as such is not

104 Muhāsibī, al-Ricāya, 37-38. It should be noted that for Muhāsibī, these rights are not limited to the accomplishment of ritual or legal norms, but include spiritual attitudes such as sincerity, confidence and awareness.

105 However, al-Qāḍi 'iyāẹ is not the first author to have made this transposition, even if he is the one who developed it in a systematic manner as the key notion of the normative aspect of his prophetology. In the sub-chapter "On his affection for his community and compassion for it", which is part of the chapter on "Love for the Prophet" of his Shu'ab al-īmān, Bayhaqī quotes his source Abū 'Abdallāh al-Ḥusayn al-Ḥalīmī (d. 403/1012): "If the reasonable person reflects on the benefits that God conferred on His servants through the Prophet in this world, and what He conferred to them through his favour of his intercession in the other world, he knows that there is no right, after the rights of God, more incumbent (lā haqqa awjab) than the right of the Prophet" (Shu'ab al-immān, II, 165). See also Bayhaqī, Shu'ab al-ìmān, II, 193 .

106 Al-Qāọī Tyāẹ explicitly uses this theologically strong expression of intermediary (al-wāsita), notably in order to explain the meaning of Muhammad's human nature and of the inner reality of his prophetic authority, see Shif $\bar{a}, 277$. 
new. It forms the topic of sub-chapters in various hadith compilations, such as Muslim's Sahịh. ${ }^{107}$ In this context, love for the Prophet appears to be a sign of the quality of one's faith, or the condition for its plenitude. ${ }^{108}$ In the Shifä, al-Qādī 'Iyād quotes these hadīths in the same sense, most importantly the hadith "None of you has faith until he loves me more than his child, his father and the whole of mankind", and in another version "None of you has faith until he loves me more than his own soul [or: than himself]".109 What is new in al-Qāḍi 'Iyạd presentation is that love for the Prophet is not simply related to faith, but that it is specified as an attitude that is due to the Prophet in virtue of his eminence, in analogy to the rights of God the fulfilment of which represents the core of Islamic spirituality. This argument becomes more explicit in al-Qâḍi 'Iyāḍ's considerations on the meaning and source of love for the Prophet Muhammad.

\subsection{Meaning and Source of Love for the Prophet (mahabbat al-nabì)}

Similar to the concept of huqūq al-nabī, al-Qāḍi 'Iyāḍ's elaboration of the theme of love for the Prophet, appears to be a creative adaptation of the theme of love for God, besides being the first of its kind in doctrinal sophistication and depth. By the time and within the milieu of al-Qāạī 'Tyāọ, Ghāzāli’s elaboration of the theme in his Ihy $\bar{a}$ ' constituted the primary doctrinal reference. ${ }^{110}$ In fact, it appears very clearly that the author of the Shifä drew inspiration in

107 Cf. Muslim, Șahịh, Kitāb al-ìmān, chapter 16 "Concerning the obligation of love for the Messenger of God".

108 See below.

109 'Iyāẹ, Shifā', 232. Both versions can be found in Bukhārī, Șahīh, kitab al-īmān, bāb hubb al-rasūl min al-ïmān, $\mathrm{N}^{\circ} 15$ and kitab al-aymān wa al-nudhūr, bāb kayfa kānat yamīn $a l-n a b \bar{\imath}, \mathrm{N}^{\circ} 6257$. Al-Qāḍī 'Iyāạ gives his own isnād for the first version with a slight variation in the order between "father (wälid)" and "child (walad)" corresponding to the version of Muslim, Șaḥịh, kitab al-īmān, bāb wujūb mahabbat al-rasūl, $\mathrm{N}^{\circ}$ 70. In his commentary of Muslim's Șahịh, al-Qāạī 'Iyāḍ offers an interesting explanation of the two hadìth mentioned in this sub-chapter: "The categories of love are three: love due to reverence and exaltation as love for the father, love due to mercy and affection as love for the child, and love due to benefaction (istihsānn) and alikeness (mushäkala) as love between people. And the Prophet reunites all these in himself. [...] And from what we said it ensues that faith does not become complete without realising (tahqiq) the elevated dignity (qadr) and rank of the Prophet above every father and child as well as above every benefactor. Whoever is not convinced of this and believes something else is not a believer (laysa bi-mu'min)" (Ikmāl al-Mu'allim, I, 280-81).

110 His important teacher Abū Bakr Ibn al-'Arabī (d. 543/1148) is, among the contemporaries of Ghazālī, "the most important source of information about al-Ghazālī's life and his teachings" (Griffel, Philosophical Theology, 62). On the role of Ibn al-'Arabī for the evolution of theological thinking in the Islamic West, see Serrano, Diffusion. 
several ways from the magnus opus of the great Persian theologian and Sufi. Similar to Muslim philosophers inspired by Neo-Platonism, Ghazālī argues that the knowledge of an object or a person increases love for it. ${ }^{111}$ This elucidates very well the argumentative connection between the first and the second part of the Shifä' in view of its overall purpose: the knowledge of the Prophet's qadr expounded in the first part leads the reader to increase his love for him.

Al-Qāḍī 'Iyāḍ first defines love in a chapter on God's love for the Prophet Muhammad as it is expressed in the latter's specific designation habīb Allāh ("the beloved of God") mentioned in a hadith:112

The root $(a s \underline{l})$ of love is the inclination towards what is in harmony with the lover (al-mayl ilā mā yuwāfiq al-muhibb). ${ }^{113}$ As for God's love for a creature, it means enabling him to attain felicity, protecting him, guiding him to success, providing him with the means to draw closer to Him, and bestowing His grace upon him, and finally to take away the veil from his heart so that he perceives $\operatorname{Him}($ yarāhu $)$ with his heart and gazes (yanzura ilayhi) towards Him with his inner sight (bașira), until he is as [God] said in the hadith [qudsi] 'and when I love him, I am his hearing through which he hears, his sight through which he sees, and his tongue through which he speaks $[\ldots]^{\prime}{ }^{114}$

If applied to God's supreme object of love, which according to al-Qādị 'Iyāḍ is the Prophet Muhammad, the hadith shows how to love the Prophet means to love the one whose whole being is animated and transcended by God's love.

The chapter on love for the Prophet deals more specifically with mankind's love for the Prophet Muhammad. Here al-Qāḍi 'Iyāḍ devotes a complete subchapter to the "meaning $\left(m a^{\prime} n \bar{a}\right)$ of love for the Prophet".115 Again, Ghazālìs

111 Ghazālī, Ihyā', IV, 392. "It is not possible to imagine the existence of love except after perception and knowledge; hence, the human being loves only what he knows". See also Abrahamov, Divine Love, 70.

112 'Iyād, Shifä', 130-133: "[...] am I not the beloved of God, without any pride?". There is no full isnād given by al-Qāḍi 'Iyād, but the hadīth is to be found amongst others in the Sunan of Tirmidhī, Kitāb al-manāqib, bāb fi faḍll al-nabī, $\mathrm{N}^{\circ} 3616$.

113 'Iyād, Shifä', 132. It is possible to translate also "the inclination towards what corresponds to the lover".

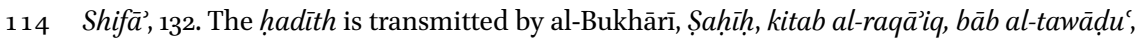
$\mathrm{N}^{\circ}$ 6137. Al-Ghazālī also cites it in his section on "God's love for the servant" and discusses it at length in order to develop the concept of qurb or nearness to God through the assimilation of divine attributes as expressed in the prophetic "noble characters" (makārim al-akhlāq), Ihyā', IV, 431-33, and also 405 .

115 Shifä, $238-39$. 
elaboration of the meaning and sources of love for God seems to have informed the argumentative basis of the Shifä̀. For Ghazālī, love is the supreme spiritual station to which all the other spiritual stations aim and thus it is the climax of man's relationship to God. His intention is to prove that only God is worthy of love and that every kind of love has its real origin in love for God. ${ }^{116} \mathrm{He}$ enumerates five causes (asbāb) of love in general, and corresponding causes of the love for God in particular. ${ }^{117}$ Al-Qāḍi 'Iyāḍ does not transpose all of these five causes to the Prophet, but chooses three of them and adapts them, since the five causes of love for God are based on the relationship between Creator and created. The author of the Shifä bases his elaboration on an albeit anthropologically orientated version of the definition of love mentioned above: "The inclination of the human being towards what is in harmony with him (al-mayl ilā mā yuwāfiq al-insān)". ${ }^{118} \mathrm{He}$ distinguishes three forms of the "harmony" (muwäfaqa) which engender love and correspond to the three reasons or sources of man's love for something or somebody: 1) harmony consisting of the pleasure felt through the "perception (idräk) of beautiful forms (al-șuwar al-jamila)" through the senses, 2) or of the pleasure felt through "perception of noble interior meanings (ma'āni bățina sharîfa) through the intellect and the heart", or 3) of the benevolence and the favour that it represents to him, for "the souls are fashioned in a way that they love the one who acts beautifully towards them (man ahsana ilayhā )".119 According to al-Qaadịi 'Iyāḍ, the Prophet Muhammad combines the three meanings/reasons of love in the most accomplished manner through 1) the beauty of his exterior appearance, 2) the perfection of his inner character, and 3) his favours and bounties on his community. ${ }^{120}$ The author of the Shif $\tilde{a}$ ' concludes that the Prophet is the worthiest creature of being truly beloved. ${ }^{121}$

In this way, al-Qāọī Iyāḍ is able to argue that love for the Prophet Muhammad is not something which needs to be imposed from the exterior, but that it is anthropologically rooted. A sound knowledge of the Prophet's eminence will naturally engender love for him in the human being, because the inclination for beauty is natural for humans. Ghazālī's definition of beauty, as "existence of all possible perfections in an object means its being in an utmost degree of

\footnotetext{
116 Al-Ghazālī, I Ihyā’, IV, 398.

117 Al-Ghazālī, Ihy àa', IV, 392-397. See also Abrahamov, Divine Love, 45-51.

118 Shifä', 238. See al-Ghazali's definition of love: "Love is the expression for the natural inclination for a thing which produces pleasure", Ihy $\vec{a}^{\prime}, \mathrm{IV}, 392$.

119 'Iyāḍ, Shifā', 238.

120 'Iyād, Shifä', 238.

121 'Iyāḍ, Shifä', 238-39.
} 
beauty",122 is influenced by Platonic and Stoic philosophy. It is certainly helpful to grasp this argument: if love is related to beauty and the pleasure produced by its perception, beauty is in reality an expression of perfection, so that love is ultimately engendered by perfection. In this sense, the perfection of the prophetic person is the reason for the pleasure that the perception of his beauty engenders in the one who has knowledge of it. For Ghazālī, the quality of being free from defects and vices necessitates love, which explains man's love for prophets and righteous people and finds its perfection only in God. ${ }^{123}$ Considering this argument, the connection in the Shif $\bar{a}^{\prime}$ between Part II on the Prophet's rights ( $h u q u \bar{q} q$ ), and Part III on his infallibility ('ișma) becomes clear: the fact of knowing that the Prophet is free from defects necessitates and increases love for him. While this quality finds its perfection in an absolute sense only in God as expounded by Ghazālī ${ }^{124}$ in the domain of creation, it finds its perfection in the Prophet only. ${ }^{125}$ This line of thought shows how the theme of love to the Prophet is directly related to the consideration of the prophetic appearance and virtues expounded in Part I.

\subsection{The Prophetic Appearance and the Perception of His Beautiful Forms} The second chapter of Part I, "On God's perfecting [the Prophet's] physical and interior qualities and His singularly unifying all religious and worldly favours in him",126 is explicitly addressed to the "lover of this noble Prophet and seeker of the details of the beauty of his exalted status". ${ }^{27}$ The various subchapters consist mainly of thematically arranged hadiths and draw the image of a human being endowed by God with the realisation of perfection in every aspect of its existence. This perfection, however, not only has an anthropological significance as it establishes the Prophet as a human ideal worthy of emulation. It equally conveys a prophetological meaning related to divine revelation. If the descriptions of "the beauty of his physical constitution"128 reproduce late-antique Arabian aesthetic ideals, ${ }^{129}$ they also convey the transfiguration of the Muhammadan being by the revelation of the divine word. His personality

\footnotetext{
122 Ghazālī, Ihyyā', IV, 396. See also Abrahamov, Divine Love, 49.

123 Abrahamov, Divine Love, 56.

124 Al-mustahiqq li-l-mahabba huwa Allāh wahduhu, "He who is worthy of love is God alone" (Ghazālī, Ihyyà) IV, 398).

125 See also Bayhaqī who writes in his Shu'ab al-imān "he [the Prophet Muhammad] is the most worthy of love (huwa ahaqqu bi-l-mahabba)", Shu'ab al-ìmān, II, 133.

126 'Iyāạ, Shifä', 44.

127 'Tyāẹ, Shifä', 44.

128 'Iyād, Shifä', 46-48.

129 See especially the summary that al-Qaḍi 'Iyāḍ gives of the various detailed descriptions of his physical appearance, Shif $\bar{a}, 46-47$.
} 
becomes a mirror of divine severity and awfulness (jalāl), and, at the same time, of His gentleness and beauty $($ jamā $l) .{ }^{130}$

The testimonies of those contemporaries who had an intimate relationship with the Prophet, such as 'Alī b. Abī Tālib, are particularly expressive: "Whoever saw him, he spontaneously had a reverential awe of him, and whoever mixed and got acquainted with him, loved him,",131 and "I have never witnessed his peer, either before or after him".132 Abū Hurayra is reported to have said: "I saw none better and more beautiful (ahsan) than the Messenger of God. It was as if the sun was running in his face, and when he laughed, he radiated and his gleam reflected on the wall". ${ }^{133}$ His hygienical and ritual "purity", 134 manifested for example through the unique perfume that his body exhaled and through the innate conformity to the Abrahamic model of bodily hygiene, reflects the immaculateness of humanity's primordial nature (al-fitra) which Islam claims to restore. As with the motive of physical beauty and harmony, al-Qāḍi 'Iyāẹ insists on the singularity of Muhammad's personality:

God favoured him with traits and attributes found in no one else, and then perfected them with the purity of revealed religion (nazāfatal-shar ), and with the ten qualities of primordial nature (khișāl al-fițra al-'ashr). ${ }^{135}$

His superior intelligence and wisdom, ${ }^{136}$ and its manifestation through "the force of his senses" and his eloquence, ${ }^{137}$ shows how God's grace was fully manifested in the personality of the Prophet Muhammad. Al-Qāḍī Iyāọ illustrates this by quoting, among others, the known transmitter of hadith and of biblical material, Wahb Ibn al-Munabbih (d. $110 / 728$ or $\left.114 / 73^{2}\right)$ :

130 Both notions, classically used to categorise the divine names, are regularly employed by al-Qāḍī 'Iyād with regard to the Prophet Muhammad, for example Shifä', 44 where he evokes the "qualities of gentleness/beauty and perfection", and Shifä’, 45 where it is question of the Prophet's "qualities of perfection and severity/awfulness". See also Gril on "De la crainte révérentielle à l'amour" in "Attitude des Compagnons", 33-37.

131 'Iyāạ, Shifä', 48.

132 'Iyāḍ, Shifä', 48.

133 'Tyāọ, Shifä' 48.

134 'Iyād, Shifä', 48-51.

135 'Iyāạ, Shifä', 48. The latter are not mentioned in detail, which shows that the author presumes that the reader knows the relevant hadiths. The same applies for the other descriptions of the Prophet's appearance which he only summarises.

136 'Iyāḍ, Shifä', 51-52.

137 'Iyād, Shifä', 53-6o. 
I have read seventy-one religious scriptures and they unanimously stated that compared to the intellect ( $a l^{-}$-aql) of the Prophet, God has not allotted to mankind, from the beginning of this world to its end, but a grain of sand from the world's sands. ${ }^{138}$

The theme of noble ascendance, ${ }^{139}$ treated in the consecutive sub-chapter, connects the Prophet Muhammad with the universal history of salvation and the community of prophets, sages and civilising heroes, and demonstrates the conclusiveness of his message. ${ }^{140}$

However, by presenting a detailed description of the Muhammadan person, the Shif $\vec{a}$ does not, in fact, introduce a wholly new theme, nor does this reflect an innovative conception of prophetology. In her groundbreaking study on the veneration of the Prophet in Islamic piety, Annemarie Schimmel has referred explicitly to the concept of the Prophet's beauty, both "physical"141 and "spiritual" 142 as an ongoing theme and preoccupation in Islamic thought, especially with hadith scholars and Sufis. The specific conception of the Prophet's body, to which the considerations of his physical beauty and perfect constitution are obviously related, can in fact be found well before the Shifa $\overrightarrow{\text { ? The }}$ particular significance of the Prophet's body in Islamic sources has been elucidated by Denis Gril, who explains: "The body of the prophets, and of the Prophet in particular, therefore reveals qualities and virtues that transcend ordinary humanity, just as their lives are identified with the mission in which they are invested". ${ }^{143}$

This is further explained by him as follows:

Thaumaturgical property of the prophetic body [...] goes hand in hand with the eschatological hope that attaches itself to it [...]. It is normal for a body through which the [divine] Word flows to be penetrated by its power of regeneration and healing. However, the attention given first by

\footnotetext{
138 'Iyād, Shifä', 51 .

139 'Iyāḍ, Shifä', 6o-61.

140 See Rubin, Eye of the Beholder, 7.

141 On "The Prophet's physical beauty", see Schimmel, And Muhammad, 33-45. Schimmel refers herself directly to al-Qāọī 'Iyāọ whom she qualifies falsely as "noted enemy of the Sufis" (33), repeating thereby a view that is based on a remark by al-Sha'rānī (d. 973/1565) the origin of which "must be understood as a mix-up of historical facts, anecdotes and overly interpretative assumptions, chiefly motivated by concerns not related to 'Iyāḍ's work, biography or legacy" (Eggen, "A book burner" 106).

142 On "The Prophet's spiritual beauty", see Schimmel, And Muhammad, 45-55. See also Andrae, Person Muhammeds, 199-228.

143 Gril, "Corps du Prophète", 37-57.
} 
the Companions and then by subsequent generations of Muslims to the physical aspect of the Prophet and his character is also explained by the idea that each of his traits may have meaning, in accordance with the laws of physiognomy, and that the impression of harmony and balance that emerges from his person reflects his physical and spiritual perfection. ${ }^{144}$

Luca Patrizi shows how a comparative perspective from the history of religions allows to understand the iconographic function of the descriptions of the prophetic person:

In Islam, writing takes the place of iconography, and as long as the Qurān is the word of God made book, Qur'anic writing takes the place that the icon in particular, and the image of Christ in general, has in Christianity. In place of images, moreover, there is the use of the physical description of the Prophet Muhammad, taken from the reports made by his companions. ${ }^{145}$

The shamāil thus compensate the physical disappearance of the Prophet and allow post-prophetic generations of Muslims to experience a visual encounter with the Muhammadan personality.

What is particular to the Shifä, is the fact that this discourse on the prophetic person is integrated into a systematic elaboration of the meaning of these descriptions for the religious life of Muslims, in particular in its normative dimension as it is expressed through the concept of huqūq and more specifically in its relation to love for the Prophet. ${ }^{146}$ Al-Qāḍi 'Iyạd inserts the shamāil genre of hadith literature into an argumentative framework based on the relation between the perception of beautiful forms and love for the Prophet. He speaks explicitly of the impact that these descriptions have on people's "hearts" 147 and, while treating the "qualities of perfection", he begs God "to illuminate my heart and yours and to increase my love and your love for this noble Prophet". 148 For the author of the Shif $\tilde{a}$, the elucidation of the

\footnotetext{
144 Gril, "Corps du Prophète", 45.

145 Patrizi, "Impronte, ritratti", 92. On this theme see also the recent thesis by Hiba Abid, Daläil al-Khayrāt, $278-97$.

146 Comparing Tirmidhỉ's Shamā’il and the Shifä’, Tor Andrae remarks that al-Qāḍī 'Iyāḍ has "overcome the ritualistic exteriority" of the first and succeeded in expounding the "ethical value" of these descriptions, see Person Mohammeds, 204-5.

147 Shifä̀, 45 .

148 Shifa ${ }^{\prime}, 46$. Examples such as these could be multiplied. It is striking that the author seems to aim specifically the "heart (qalb)" of the reader, and less his reason ('aql). Even if he
} 
Prophet's physical appearance and of his personality clearly has a theological and a spiritual function. It is expected to have an impact on the religious life of the Muslim community in its fulfilment of the Prophet's rights.

\subsection{The Prophet's "Beautiful Character" and the Perception of His "Noble Meanings" and of His Benevolence}

The same can be said of the second source of love for the Prophet, which is identified by al-Qāḍi 'Iyā as "the perception of noble interior meanings", by which he means the Prophet's virtues and his character or khuluq. ${ }^{149}$ The reason for this lies, according to the author, in the fact that "the human being is naturally inclined towards being very fond of [saintly people, scholars and virtuously acting people] to the extent that certain people are led to partisanship (ta'așșub) and others to sectarianism (tashayyu ')."150 This remark again establishes an anthropological foundation of love for the Prophet Muhammad, as for al-Qāḍi 'Iyạd the latter is obviously the most eminent of saintly and righteous people. And indeed, in the corresponding section of the Prophet's description, the author seeks to demonstrate that the personality of Muhammad encompasses the totality of those qualities on whose excellence both reason and revelation agree:

They are called 'the beautiful character' (husn al-khuluq) and this is the equilibrium of the soul's faculties and attributes, and their just balance without any inclination towards the transgression of their limits. The totality of these qualities was the character of our Prophet, with regard to the culmination of their perfection and to their accomplished equilibrium, to the extent that God praised him in His statement "And verily, you are of an exalted character" (Q 68:4). 'Â'isha said: "His character was the Qur'ān, he was satisfied by its satisfaction and he was discontent by its discontentment", 151 and he said "I was sent to accomplish the noble

constructs a reasoning in order to strengthen his argument, he seems to consider that the presentation of scriptural evidence, with its descriptive, edificatory and narrative elements, is more effective for impressing the religious consciousness of his readership than discursive deliberations.

149 Shifä̀) 238.

15 One could see here a hidden criticism of the religious-political circumstances of his time. However, this conception is probably taken from Ghazālī according to whom "spiritual qualities are beloved and the person qualified by them is by nature beloved by whoever knows his qualities. The proof for this is the fact that people by nature love prophets, the Companions of Muhammad, the heads of the schools of law, such as Shäfīi, although they did not see them" Abrahamov, Divine Love, 49.

151 See Muslim, Șaḥịh, kitāa șalāt al-musāfirīn, bābjāmis șalāt al-layl, $\mathrm{N}^{\circ} 746$. 
character traits". ${ }^{152}$ And Anas [Ibn Mālik] said that the Messenger of God was the most beautiful of men in character, and 'Alì b. Abī Țālib said the same. As the veritable knowers (al-muhaqqiqūn) remember him, he was fashioned on these [beautiful character traits] in the root of his constitution and of his immaculate original nature (awwal fitratihi); he did not obtain them through acquisition or exercise, but only by divine generosity and lordly election, and this is true for all the prophets. ${ }^{153}$

It is interesting to see how the author mingles philosophical and theological ethics. In fact, he mentions at various places the "insightful thinkers" ('uqalä) or the "people of sound reason (așhāb al-uqūl al-salima)" as an authority complementary to the revealed law (al-shar $)^{\prime}$ for the appreciation of attributes and characters. ${ }^{154}$ Already Tor Andrae ${ }^{155}$ alluded to the influence of Aristotelian ethics as elaborated in Islamic terms by Miskawayh (d. 421/1030), probably through the mediation of Ghazâli's Ihya $\bar{a}^{\prime},{ }^{156}$ but also to the impact of pre-Islamic Arabian ethical ideals like the muruwwa (chivalry). Al-Qădị 'Iyād indeed begins, in the manner of the philosophers, the list of virtues with the Prophet's intellect ('aql) by explaining that it "constitutes the root of the branches [of the beautiful character], the origin of its sources and the centre of its sphere". ${ }^{157}$ But unlike the philosophers, the author of the Shifä' considers the

$15^{2}$ See Bukhārī, al-Adab al-mufrad, bāb ḥusn al-khuluq, $\mathrm{N}^{\circ} 273$ and Niṣābūrī, al-Mustadrak, kitab al-tawārīkh, bāb āyāt rasūl Allāh, $\mathrm{N}^{\circ}{ }_{4221}$. However, in both sources the hadīth is narrated with the wording șăliḥ al-akhlāq (virtuous character traits).

153 'Iyād, Shifä̀, 68-69.

154 See, for example, at the beginning of the section of the akhlāq (Shifä), 68). However, al-Qāḍī 'Iyāḍ précises immediately afterwards that it is the revealed law that commands their acquisition and elucidates their soteriological meaning: "The revealed law praises all of them, commands their acquisition and promises the eternal beatitude for the one who assimilates them (al-mutakhalliq bi-hā) and qualifies himself with some of them, for the reason that they represent a part of prophecy" (Shifä), 68).

155 'Iyāọ, Shifä̀', 206-12.

156 On this transfer of virtue ethics "from philosophy to scripture" through Miskawayh and Ghazālī, see Zargar, Polished Mirror, 79-105. For a discussion of this theme in al-Ghazālī, see Abul Quasem, Ethics of al-Ghazali.

157 'Iyāạ, Shifä', 71. The author admits that this chapter is somewhat a repetition of what he stated in the section of the Prophet's constitution, and of what he will state in the section on the Prophet's miracles. This shows how important it was for al-Qāḍī 'Iyāẹ to deal with this theme, probably in view of demonstrating to his philosophically orientated contemporaries the eminence of the Prophet Muhammad, and his superiority towards the Greek masters of rationality. 
prophetic intellect and the various aptitudes which issue from it with regard to the Qurānic doctrine of Muhammad's illiterateness: ${ }^{158}$

According to his intellect, he had knowledge of everything God taught him and made him understand, including the science of what has been and of what will be, of the wonders of His power and the immensity of His transcendent realm, as God says 'and He taught you what you did not know and God's favour upon you is immense' (Q 5:113). [Human] intelligences became perplexed at measuring God's favour on him and the tongues fell into silence when attempting to express a comprehensive description of this. ${ }^{159}$

While affirming in this last sentence, as in various other places, the relativity of philosophical knowledge with regard to prophetology, the author does not disdain to use philosophical ethics in order to make sense of the various capacities and powers attributed to the Prophet Muhammad, such as the little amount of sleep and food ${ }^{160}$ he needed, or his ability to handle wealth and to deal with political matters. This argumentative structure allows al-Qādī 'Iyāọ to make the Prophet Muhammad appear as a superior and divinely inspired version of the philosophical ideal of the philosopher-king. It is conceivable that the author of the Shifä intended thereby to argue, against the rationalist-minded amongst his contemporaries, the superiority of the Prophet Muhammad over the philosophers and the incomparability between the two types of knowledge. ${ }^{161}$

$15^{8}$ See Q 7:157. Al-Qāọī 'Iyāẹ explains that the Prophet Muhammad obtained knowledge about previous scriptures, divine commandments, virtuous conduct, the guidance of people etc. "without teaching or study, the reading of previous scriptures or the company of its scholars, nay, he was an illiterate prophet (nabi ummī) who did not know anything of this until God opened his breast, made clear his affair, taught him and made him recite" (Shifä’ 72$)$. In the time of al-Qāọī 'Tyāḍ, there has been a famous controversy in al-Andalus concerning the position held by the hadīth scholar Abū al-Walīd al-Bājì (d. 474/1081) that the Prophet knew how to write, as suggested by a hadith, but that this ability was not the result of an ordinary acquisition, but the fact of a miracle (mujiza). See Blecher, Said the Prophet, 21-29.

159 Shifä̀,72.

16o Shifä̀, 61-62.

161 He thereby is in line with the theological criticism of philosophical prophetology as analysed by Zouggar, Philosophes. On the polemics over the "acquisition of prophecy" in alAndalus in the fifth-sixth/eleventh-twelfth centuries, see Casewit, Mystics of al-Andalus, 39-42. 
Despite their philosophical relevance, these and the other qualities are obviously above all related to the prophetic mission and dignity of Muhammad. His forbearance, generosity, courage, modesty each elucidate an aspect of the prophetic function and of its Muhammadan specificity. ${ }^{162}$

However, the sub-chapter on "his compassion (shafaqa), his mercy ( $r a h m a)$ and affection $\left(r a^{\prime} f a\right)$ for the entire creation"163 certainly has a particular significance. The theme of the Prophet's mercy ${ }^{164}$ is indeed one of the major motives of the Shif $\tilde{a}$ ' as it draws through all its parts. ${ }^{165}$ Its importance stems from the fact that the Prophet's unconditional mercy constitutes an obvious indication of the singular role that God has assigned to him and thus of his eminence. ${ }^{166}$ According to al-Qāḍi 'Iyāḍ, who takes up a common theological argument, this is demonstrated in particular by the fact that by characterising the Prophet Muhammad with mercy, God attributes to the latter His own name and quality. ${ }^{167}$ At the same time, the theme of the Prophet's mercy also very clearly shows the soteriological significance of his personality, and thus the normative status of veneration and love for him. Mercy equally has a central significance because it represents the essential element of the third source of love mentioned by al-Qāḍ̄ 'Iyād, namely "the benevolence and the favour that somebody represents to man" corresponding to the Prophet's "favours and bounties on his community". 168

Considering the presentation of the Prophet's character traits in general, it is striking how al-Qāḍi 'Iyāḍ constantly stresses their divine cause, as for example when explaining in the case of the Prophet's longanimity and forbearance that "all this is from how God educated His Prophet". ${ }^{169}$ This insistence can be understood to have a double meaning. Firstly, as explained in the first part, it

162 See Shifä’ $72-97$. A precise analysis of each character trait and virtue from this perspective would certainly yield fruitful results which would deepen and differentiate our understanding of the Muslim perception of the Prophet Muhammad. However, this cannot be done here for reasons of space, and must be kept for further studies.

163 Shifä̀, 83-85.

164 According to al-Khafâjī, the term rahma as applied to a human being is explained as "the softness (riqqa) of the heart with regard to the concern of a person", Nasim, I, $15^{2}$.

165 See Shifä $, 21-23,39,83-85,142,145$. In the sub-chapter discussed here, the mercy motive is explained in terms of its ethical meaning as characterising the way the Prophet engaged with people, whereas in the other sections, the Prophet's mercy is considered more in terms of the meaning of his sending. See also Vimercati Sanseverino, "Wer dem Gesandten gehorcht", 68-7o.

166 See Part I of this chapter.

${ }_{167}$ See Shifä, 145.

168 'Iyāḍ, Shifä', 238.

169 'Iyāẹ, Shifä', 72. 
demonstrates again the Prophet's pre-eminence and secondly, it goes against the philosophical conception of prophetology which considers prophecy as a state conferred by God on account of intellectual and moral qualities. Here, very clearly following Ash'ari theology, ${ }^{170}$ the author of the Shifä emphasises that the prophetic virtues represent the consequences of divine election and revelation for the prophetic person. There is no causal relation between human qualities and prophecy - both are nothing other than effects of God's will and grace.

At the same time, the influence of Sufi ethics is visible through the various quotations and also through certain themes. ${ }^{171}$ Whereas the great majority of attributes concern the Prophet's relation to people, there is only one category which exclusively concerns his relation to God, namely one of the last subchapters dealing with "his fear of his Lord, his obedience towards Him and the intensity of his adoration". ${ }^{172}$ The Shifă seems to emphasise a certain type of spirituality which reflects the spiritual and ethical ideal of al-Qāḍī 'Iyāḍ's milieu and time. Detachment from worldly affairs (zuhd), combined with a rigorous and intense ritual practice, and the vigilant fear of God as the principal modality of knowledge of God, correspond to the ideal of the ascetic scholar-saint characteristic for the Islamic West of the fourth-sixth/tenth-twelfth centuries. ${ }^{173}$

From these considerations it becomes clear how al-Qāḍi 'Iyāạ skilfully arranges these various discursive genres towards a common theme, that is the love for the Prophet. A more normative approach is visible in the sub-chapter on "The signs of love for the Prophet", 174 the longest of this whole chapter and, to my knowledge, the first of this kind in the history of Sunnī literature. The theme of "signs" offers criteria in order to verify the sincerity (șidq) of love for the Prophet Muhammad. Even if there are no explicit indications, the question arises whether the author had in view false claims of love for the Prophet in

170 On al-Qāḍī 'Iyāḍ's Ash'arīsm, see Serrano, Diffusion de l'ash'arisme and also Al-'Abdallāh, Juhūduhu al-kalāmiyya; Shawwāt, 'Ālim al-Maghrib, 46-56.

171 A specific study on the influence of Sufism on the Shifä is yet to be undertaken. At this stage of research, the work gives the impression of a certain preponderance of quotations attributed to Sahl al-Tustarī. Regarding themes besides virtues like renunciation or fear of God, one can mention the issue of the Prophet's characterisation with divine names and the elaborations on love for the Prophet. For the latter theme in early Sufism, see Thibon, "Transmission du hadith".

172 'Iyād, Shifä', 95-97.

173 See Vimercati Sanseverino, "Hagiographie marocaine"; on the "Renunciant Tradition in Seville" in particular Casewit, Mystics of Andalus, 30-33. However, even later prophetological works such as Qasțallānī (d. 963/1517), al-Mawāhib al-laduniya (see II , 83-115), adopt the same scheme.

'Iyāḍ, Shifä', 235-238. 
his time and whether this theme possibly contains a veiled critique against a certain group which, in al-Qāḍī 'Iyāḍ's view, claimed to represent the Prophet's authority and to be attached to him, without laying importance on the requirements of "prophetic piety". ${ }^{175}$ In any case, the "signs" that he mentions illustrate very concretely the effects of love for the Prophet on religious life: the preference for the Prophet and for conformity to him, continuous mention of him (dhikrihi) and desire to meet him, especially when one hears his name, love for those associated to him like his family and companions, love for the Qurān and finally compassion for his community. ${ }^{176}$ Far from being merely an interior attitude, the mahabbat al-nabi requires the whole being of the believer, in order to be truthful (șādiq). In fact, love for the Prophet represents for the author of the Shifä a comprehensive and programmatic vision of the practice of Islam, involving the interior life of the individual believer as well as his exterior behaviour and his relationship to the community. This comprehensive character of the love for the Prophet results from its normative meaning:

Know that who loves something accords preference to it and conformity to it, otherwise his love is not truthful, but he pretends only to it. He who is sincere in his love for the Prophet is the one on whom its signs appear, and the first sign is taking him as a model, putting his Sunna into practice and following his words and deeds, as well as conforming to his commands and interdictions, educating oneself according to his behaviour in facility and difficulty, as well as in pleasant and unpleasant things; the evidence of this, is God's word 'Say: If you love God, then follow me and God will love you (Q 3:31)'. And [love for the Prophet] is also apparent through giving preference to what he legislated and urged to do, against what conforms to one's own passions and desires. ${ }^{177}$

In the sub-chapter "On the reward (thawāb) for love for the Prophet",178 interestingly placed at the very beginning, al-Qādị 'Tyād dwells in particular on the eschatological meaning of the fulfilment of the duties connected with this love. The argument developed through the various hadith is that loving the

\footnotetext{
175 One could think of both, the current of Mālikism which preferred to stick the authority of its scholars and thereby neglecting the hadith (see Fierro, "Proto-Malikis"), or the Almohads who sought to place the Mahdī as normative and theological reference for the Muslim community (see Fierro, "El tratado").

${ }_{176}$ For all these see 'Iyād, Shifä’ 2366 .

177 Shifä, 235 .

${ }_{17} 8$ Shifä, $232-33$.
} 
Prophet means being associated with the one who will be in the most blissful position in paradise: "Whoever loves me, will be with me in paradise".179

In this relatively small passage, the soteriological argument of the Shifä' and of its prophetology comes more fully into light. The theme of "reward" allows the writer to expound what the Prophet's pre-eminence means for his community, and how the fulfilment of his rights constitutes the modalities through which his community can itself benefit from it. If "being with the Prophet" is the supreme reward of love for him, and thus the true goal of the fulfilment of his rights in general, ${ }^{180}$ then because it means to be associated to the grace for which God singled out the Prophet Muhammad. It is in this sense, that the Shif $\tilde{a}$ ' argues that the quality of a believer's relationship to God is dependent upon the quality of his relationship to the Prophet, which is proportionate to his love for him. In other words, the believer's relationship to God is only a relationship of effective proximity and love if it is goes along with an effective relationship to the most near and beloved creature to God, which is the Prophet Muhammad. Because God loves the Prophet, to love the Prophet means to participate in God's love for him.

\section{4 Conclusion}

One of the results of this study is certainly to have shown the theological complexity and sophistication of a work that has too often been treated as a polemical or apologetical text whose purpose resided in promoting extravagant beliefs to credulous Muslim masses. Focusing on the central notions of $q a d r$ and $h u q \bar{u} q$, as well as the themes of knowledge and love, this analysis of the Shif $\bar{a}$ ' has attempted to demonstrate how the veneration of the Prophet Muhammad represents a genuine theological and intellectual concern within Sunni scholarly discourse. Drawing on the rich textual material of the various genres of prophetological literature, the Shif $\bar{a}$ ' uses sciences and approaches as diverse as hadith, philosophy and Sufism in order to show how evidence for Muhammadan prophethood is first of all soteriologically meaningful for the religious life of Muslims. Developing the prophetological scope of various discursive traditions, the Shif $\bar{a}^{\prime}$ thus reflects the end of the formative period.

179 Shifä, 233 .

180 This conclusion is further confirmed by the other chapters, especially the final, very ample, chapter of Part II which concerns the practice of tasliya or "praying for the Prophet" (al-șalät 'alä al-nabì) and wherein various hadīths are mentioned to this effect. For the theme of tașliya see the excellent study of Hamidoune, Prière sur le Prophète. 
In the context of the emergence of schisms and of the threats to the territorial integrity of the Islamic West, it participates in the consolidation of a distinct Sunnī identity shaped by "Muhammadan spirituality".

The study of the Shif $\tilde{a}$ ' allows for a more differentiated understanding of the Muslim discourse on the Prophet's pre-eminence. For those who believe in Muhammad's prophetic claim and strive to follow him, the latter's exalted dignity means, foremost, the possibility to participate in the Prophet's nearness to God - hence, proximity to the Prophet implies proximity to God. If Part I shows that through the Prophet Muhammad the believer has access to a privileged relationship with God, Part II responds to the question how this participation is possible, namely through the fulfilment of his rights, love for the Prophet representing their ultimate fulfilment.

What is striking is the epistemological consistency of this prophetology: If it is God Himself who imparts knowledge about the Prophet's pre-eminence to mankind, man cannot attain this knowledge by himself - at least in its depth, variety and veritable meaning. Consequently, al-Qādị 'Tyāḍ organised his prophetology according to the loci of God's exaltation of the Prophet, i.e., God's speech to the Prophet, and the Prophet's person and miraculous acts as transmitted by tradition. If al-Qāạī 'Iyāọ presents revelation and salvation history as sources for the knowledge of the Prophet's pre-eminent status, the question arises which role he accords to reason or 'aql? While further analysis is needed on this point, it can be already affirmed in a general manner that reason as a purely human source of knowledge seems to have only a secondary epistemological significance, which is limited to demonstrating the plausibility of an argument rather than allowing for certainty with regard to its truth. So rather than a source of knowledge, reason appears as a hermeneutical instrument needed for making the meaning and coherence of the mentioned sources evident in view of a certain theme. Hence, al-Qāḍi 'Tyāạ's "concessions" to philosophical ethics are in fact only relative: if reason is able to appreciate the Prophet's virtues and to elucidate their excellence through systematic elaboration, it is incapable of recognising their true meaning and the reality of the Prophet's realisation of them. However, if the value of reason for the knowledge of the Prophet's eminent reality appears to be relative, one should not conclude that for al-Qāḍi 'Iyāḍ the 'aql is negligible. The third part of the book, which, according to its author, contains the "secret" of the whole work, shows that the use of reason is indispensable for an accurate understanding of the subtleties of prophetology.

Despite the insights yielded by this study, it is clear that the Shifás requires further analysis of the other two parts and of certain aspects, in particular the theme of hadìth transmission which occupies a central place for al-Qādî̀ 
'Iyāḍ's self-understanding and activity as a scholar. If the Shifä' argues the soteriological necessity of the Muslim's relationship to the person of the Prophet, the hadith represents one of the major means through which this relationship is established. ${ }^{181}$ Another aspect to be inquired further is the influence of Ghazālī's thought on al-Qaaḍī 'Iyạd, and of philosophical ideas and of Sufi teachings in general. If the Shifă shows obvious parallels to both, the concrete genealogy of certain ideas has to be elucidated further. Against the background of a more comprehensive understanding of the Shifäa, it will be possible to relate its argument as expounded in this study more concretely to al-Qādî 'Iyāḍ's diagnostics of the Muslim community's situation in his time. ${ }^{182}$ It is the latter which elucidates how for al-Qāḍī 'Iyāọ the inappropriate or incomplete understanding of the prophetic reality of Muhammad's personality constitutes the real cause for the neglect of the Prophet's rights in the Muslim community, and hence the root of the latter's critical situation.

Certainly, the most singular feature which this study has brought to light is the elaboration of a veritable theology of veneration of the Prophet in the Shifä. One can speak of a theology in the sense that the conceptualisation of veneration is grounded in the divine determination of prophetic dignity, which is only known by God's revelation and working. Love for the Prophet, as al-Qādī 'Iyāẹ presented it, is ultimately based on God's exaltation of the Prophet in words and acts. For a scholar like al-Qāḍī 'Iyāḍ, the mahabbat al-nabī is not merely a moral device or an emotional impulse related to the socio-religious or psychological needs of the Muslim community but has its foundation in revelation and tradition and thus can be substantiated through theological reasoning. Furthermore, it is a theology because it develops a comprehensive vision of Islamic religious life founded on the Muhammadan model and personality. The latter appears as an ideal of human perfection, allowing thereby for an anthropological basis of veneration: the human being inclines naturally to what is beautiful and good, and the Prophet Muhammad, reuniting in him the outer and inner qualities of perfection with benevolence towards mankind, represents the supreme object of love in the created world. It is this vision which most likely explains the singular success of the Shifä), as well as its continuing relevance and force of attraction.

181 See my forthcoming study on this aspect of the Shifä' and of hadith transmission in M. Gharaibeh, ed. Beyond Authenticity, forthcoming.

182 This is certainly to be understood in view of what Maribel Fierro calls "spiritual alienation", see Fierro, "Spiritual alienation" and Vimercati Sanseverino, "Transmission, ethos" $46-51$. 


\section{Bibliography}

\section{Primary Sources}

Abid, H. "Les Dalāill al-Khayrāt d'al-Jazūlī (m. 869/1465): la tradition manuscrite d'un livre de prières soufi au Maghreb du X $\mathrm{X}^{\mathrm{e}} / \mathrm{XVI}^{\mathrm{e}}$ au XIII $/ \mathrm{XIX}^{\mathrm{e}}$ siècles", $\mathrm{PhD}$ thesis, Paris, EPHE, 2017.

Abrahamov, B. Divine Love in Islamic Mysticism. The teachings of al-Ghazālî and al-Dabbāgh, London, Routledge, 2003.

Abul Quasem, M. The Ethics of al-Ghazali. A composite ethics in Islam, New York, Caravan Books, 1978.

Ahmed, S. Before Orthodoxy: The Satanic Verses in Early Islam, Cambridge, Harvard University Press, 2017.

'Abdallāh, K. Ḥ. Al-. al-Qāḍ̄ 'Iyāẹ wa juhūdudu al-kalāmiyya, Beiurt, Dār Nawādir al-Lubnāniyya, 2014.

'Amrī, A. J. al-, al-Sīra al-nabawiyya fìmafhūm al-Qāḍ̂̄ 'Yyāụ, Cairo, Dār al-Ma'ārif, 1988. Albarrán Iruela, J.r, Veneración y polémica: Muhamad en la obra del Qā ḍ̄ Tyād, Madrid, Ediciones de La Ergástula, 2015.

Bayhaqī, A. B. A. al-, Shu'ab al-īmān, ed. Muḥammad Ibn Basyūnī Zaghlūl, 9 vols. Beirut, Dār al-Kutub al-'Tlmiyya, 2017, 3rd ed.

Bukhārī, I. al-, al-Jāmi` al-musnad al-ṣaḥị̣ al-mukhtașar min umūr rasūl Allāh wa sunanihi wa ayyāmihi, ed. M. D. al-Baghā, Beirut, Dār Ibn Kathīr, 3rd ed. 1987.

Ghazālī, A. Ḥ. M. al-, Ihyyā' 'ulūm al-dīn, ed. M. D. Balța, 5 vols., Beirut, al-Maktabat al-Așriyya, 2015.

Ibn al-'Alawī al-Mālikī, M. Mafāhim yajib an tuṣaḥhaḥ, Beirut, Dār al-Kutub al-'Ilmiyya, 3rd ed. 20o9, (tr. S. Abdul Aziz, Notions that must be corrected, Rotterdam, Sunni Publications, 2018).

Iṣbahānī, A. N. A. al-, Dalāil al-nubuwwwa, ed. M. R. Qal'a and 'A. B. 'Abbās, Beirut, Dār al-Nafä̀is, 1986.

Kattānī, M. 'A. al-Ḥ. al-, al-Madkhal ilā kitāb al-Shifä', ed. K. al-Sibāīì, Rabat, Dār al-Amān, 2015.

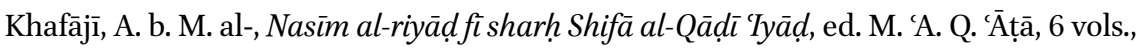
Beirut, Dār al-Kutub al-'Ilmiyya, 2001.

Maqqarī, S. D. A. al-, Ažhār al-riyāụ fi akhbār 'Tyāḍ, ed. 'Alī 'Umar, 5 vols., Cairo, Maktabat al-Thaqāfa al-Dīniyya, 2010.

Muḥāsibī, Ḥ. b. A. al-, al-Ricāyat li-ḥuqūq Allāh, ed. 'A. Ḥ. Maḥmūd, Cairo, Dār al-kutub al-ḥadìtha, 196o.

Muslim Ibn al-Ḥajjāj, A. al-Ḥ., al-Jāmi al-Ṣaḥịh, ed. F. 'Abd al-Bāqī, 6 vols, Cairo: Dār Iḥyā' al-Turāth al-'Arabī, 1954.

Nisabūrī, al-Ḥ. al-, al-Mustadrak 'alā al-Ṣaḥịhayn, ed. M. 'A. Q. 'Ațā, 4 vols, Beirut, Dār al-Kutub al-'Ilmiyya, 199 o. 
Qāọī Iyāḍ al-Yaḥ̣ubī, A. F. al-. al-Ghunya, ed. M. Z.Jarrār, Beirut, Dār al-Gharb al-Islāmī, 1982.

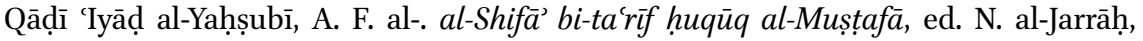
Beirut, Dār al-Ṣādir, 2006.

Qāḍ̄i 'Iyāḍ al-Yaḥ̣ubī, A. F. al-. Ikmāl al-Mu'allim fì sharḥ Muslim, ed. Y. I. Manșūra, 3 vols, Dār al-Wafā, 1998.

Qasțallānī, A. b. M. al-, al-Mawāhib al-laduniyya bi-l-minaḥ al-muḥammadiyya, ed. M. al-Jannān, 3 vols, Beirut, Dār al-Kutub al-'Tlmiyya, 2nd. ed. 2009.

Tirmidhī, M. b. 'Ī. al-, al-Sunan, eds. A. Shākir, F. 'Abd al-Bāqī, 5 vols, Cairo, Maktabat Mușțafā al-Bābī, 2nd ed, 1975 .

\section{Secondary Literature}

Ali, K. The Lives of Muhammad, Cambridge/Massachusetts, Harvard University Press, 2014.

Addas, C. La maison muhammadienne: Aperçus de la dévotion au Prophète en mystique musulmane, Paris, Gallimard, 2015.

Andrae, T. Die Person Muhammeds in Lehre und Glauben seiner Gemeinde, Stockholm, P. A. Norstedt \& Söner, 1918.

Blecher, J. Said the Prophet of God: Hadith Commentary across a Millennium, Berkeley, University of California Press, 2017.

Böwering, G. The mystical vision of existence in classical Islam. The Qurānic hermeneutics of the Șūfī Sahl At-Tustarī (d. 283/896), Berlin/New York, De Gruyter, 198 o.

Brown, J. A. C. Muhammad: a very short introduction, Oxford University Press, 2011.

Casewit, Y. The mystics of al-Andalus. Ibn Barrajan and Islamic thought in the twelfth century, Cambridge, Cambridge University Press, 2017.

Chodkiewicz, M. "Le modèle prophétique de la sainteté en Islam", Al-Masāq 7/1 (1994), 201-26.

Eggen, N. S. "A book burner or not? History and myth: Revisiting al-Qāḍ̄ 'Iyāḍ and the controversies over al-Ghazālī in the Islamic West", Journal of Arabic and Islamic Studies 18 (2018), 87-109.

Emon, Anver M. "Huqūq Allāh and ḥuqūq al-ibād. A legal heuristic for a natural regime", Islamic Law and Society 13 (2006), 325-391.

Fierro, M. "Spiritual Alienation and Political Activism. The gurabā’ in al-Andalus during the Sixth/Twelfth Century", Arabica 74 (2000), 230-26o.

Fierro, M. "El Tratado Sobre El Profeta Del Cadí 'Iyad Y El Contexto Almohade" in R. G. Khoury et al. eds. Legendaria Medievalia: En Honor De Concepción Castillo Castillo, Horizontes de al-Andalus no. 1, Córdoba, El Almendro, 2011, 19-34.

Fierro, M. "Proto-Malikis, Malikis and reformed Malikis in al-Andalus" in P. J. Bearman, R. Peters, and F. E. Vogel, ed. The Islamic school of law: Evolution, devolution, and progress, Cambridge, Harvard University Press, 2005, 57-76. 
Fierro, M. "El Kitāb al-Anwār y la circulación de libros en al-Andalus", Sharq al-Andalus (2011-13), 97-108.

Gharaibeh, M., ed. Beyond Authenticity. Towards Alternative Approches of Hadith Narrations and Collections, Leiden, Brill, forthcoming.

Gimaret, D. La doctrine d'al-Ash'arī, Paris, Cerf, 1990.

Gimaret, D. Les noms divins en Islam: Exégèse lexicographique et théologique, Paris, Cerf, 1988.

Görke, A. "Introduction: Images of Muhammad in the Course of Time" in A. Görke, ed. Muhammad. Critical concepts in religious studies, New York, Routledge, 2015, vol. I, $1-21$.

Graham, William A. "Traditionalism in Islam. An Essay in Interpretation”, Journal of Interdisciplinary History 23 (1993), 495-522.

Griffel, F. Al-Ghazālı̀s philosophical theology, Oxford, Oxford University Press, 2009.

Gril, D. "'Comme s'il y avait des oiseaux sur leur tête'. Entre vénération et amour, l'attitude des compagnons envers le Prophète", Archives de sciences sociales des religions 178/2 (2017), 25-42.

Gril, D. "Le corps du Prophète", Revue des mondes musulmans et de la Méditerranée, 113-4 (2006), 37-57.

Gril, D. "Révélation et inspiration", in M. A. Amir-Moezzi, ed. Dictionnaire du Coran, Paris, Laffont, 2007, 749-755.

Hamidoune, M. A. "La Pratique de la 'Prière sur le Prophète' en Islam. Analyse philologique et implications doctrinales", PhD thesis, Université Aix-Marseille, 2012.

Hibah, G. A.-R. Ash-Shifa. Healing through defining the rights of the Prophet Muhammad, Beirut, Dar Al-Kotob Al-ilmiyah, 2013, 2nd ed.

Horovitz, J. "The Growth of the Mohammed Legend", Muslim World 10 (1920), 269-78, repr. in: U. Rubin, ed. The life of Muhammad, Aldershot, Ashgate, 1998.

Hourani, G. F. Reason and Tradition in Islamic Ethics, Cambridge, Cambridge University Press, 1985 .

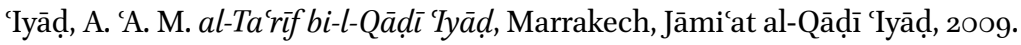

Jarrar, M. Die Prophetenbiographie im islamischen Spanien. Ein Beitrag zur Überlieferungs- und Redaktionsgeschichte, Frankfurt/Main, Peter Lang, 1989.

Katz, M. H. The birth of the prophet Muhammad. Devotional piety in Sunni Islam, London/New York, Routledge, 2007.

Kermani, N. Gott ist schön. Das ästhetische Erleben des Koran, München, Beck, 1999.

Khalidi, T. Arabic historical thought in the classical period, Cambridge, Cambridge University Press, 1996.

Khalidi, T. Images of Muhammad: Narratives of the Prophet in Islam Across the Centuries, New York, Doubleday, 2009.

Koertner, M., "We made clear signs. Dalāil al-nubuwwa - Proofs of prophecy in early Hadīth literature", PhD Thesis, Yale University, 2014. 
Laroui, A. Islam et Histoire. Essai d'épistémologie, Paris, Flammarion, 1999.

Lowry, J. E. ed. and tr. al-Shāfīi. The Epistle on Legal Theory, New York, New York University Press, 2013.

Nagel, T. "Hadīth oder die Vernichtung der Geschichte", ZDMG XXV. Deutscher Orientalistentag. Vorträge Supplementa 10 (1994), 118-28.

Nagel, T. "Die Tabuisierung der Person des Propheten Muhammad", in H. Preissler and H. Seiwert, eds. Gnosisforschung und Religionsgeschichte. Festschrift für Karl Rudolph zum 65. Geburtstag, Marburg, Diagonal Verlag, 1994, 479-488.

Nagel, T. Allahs Liebling: Ursprung und Erscheinungsformen des Mohammedglaubens, München, R. Oldenbourg, 2008.

Nasr, S. H. ed. The Study Quran. A New Translation and Commentary, San Francisco, HarperCollins, 2015.

Patrizi, L. "Impronte, ritratti e reliquie di profeti nell'Islam", in A. Monaci Castagno, ed. Sacre Impronte e oggetti "non fatti da mano d'uomo" nelle religioni, Alessandria, Edizioni dell'Orso, 2011, 81-94.

Rahman, F. Prophecy in Islam: Philosophy and Orthodoxy, Chicago, University of Chicago Press, 2011.

Reichmuth, S. "Aspects of Prophetic Piety in the Early Modern Period", Archives de sciences sociales des religions, 178/2 (2017), 129-150.

Safi, O. Memories of Muhammad: Why the Prophet Matters, San Francisco, HarperOne, 2010.

Schimmel, A. Und Muhammad ist Sein Prophet: Die Verehrung des Propheten in der islamischen Frömmigkeit, Düsseldorf, Diederichs, 1981: English translation: And Muhammad Is His Messenger: The Veneration of the Prophet in Islamic Piety, Chapel Hill, University of North Carolina Press, 1985.

Schöller, M. Mohammed: Leben, Werk, Wirkung, Frankfurt am Main, Suhrkamp, 2008.

Serrano, D. "Iyāḍ, Abū al-Faḍl", in Jorge Lirola Delgado, ed. Biblioteca de al-Andalus. De Ibn al-Yabbāb a Nubdat al-'așr, Almería, Fundación Ibn Tufayl de Estudios Árabes, 2009, 404-434.

Serrano, D. "La diffusion de l'ash'arisme et la réforme du credo malikite à l'époque almoravide. Ibn Rushd al-Jadd, Abū Bakr Ibn al-'Arabī et le qāḍi 'Iyāḍ̂", in C. Aillet and B. Tuil L. eds. Dynamiques religieuses et territoires du sacré au Maghreb médiéval. Éléments d'enquête, Madrid, CSIC, 2015, 80-102.

Shawwāṭ, Ḥ. b. M. al-Qāḍī 'Iyāọ 'ālim al-Maghrib wa imām ahl al-ḥadīth fĩ waqtihi (476-544), Damascus, Dār al-Qalam, 1999.

Silvers, L. A soaring minaret. Abu Bakr al-Wasiti and the rise of Baghdadi Sufism, Albany, State University of New York Press, 2010.

Stroumsa, S. "The Signs of Prophecy. The Emergence and Early Development of a Theme in Arabic Theological Literature", Harvard Theological review 78 (1985), 101-114. 
Thibon, J.-J. "Transmission du Ḥadīth et modèle prophétique chez les premiers soufis", Archives de sciences sociales des religions 178/2 (2017), 71-88.

Vizcaíno, J. M. "Las obras de Zuhd en al-Andalus", al-Qantara 12 (1991), 417-438.

Vimercati Sanseverino, R. "Wer dem Gesandten gehorcht, der gehorcht damit Gott' Normativität der prophetischen Tradition und Gnadenerfüllung im sunnitischen Denken der spätformativen Periode", in M. Khalfaoui and B. Ucar, eds. Islamisches Recht in Theorie und Praxis, Frankfurt/Main, Peter Lang, 2016, 57-77.

Vimercati Sanseverino, R. "Combat Prophetology, Sīra and Hadīth: Considerations about Some Approaches in Academic Islamic Theology in View of the Jihadist Reference to the Prophet Muhammad", in M Bedir, N. Kızılkaya and M. Özaykal, eds. Modernleşme, Protestanlaşma ve Selefilleşme: Modern İslam Düşüncesinde Nassın Araçsallaştırılması, Istanbul, ISAR, 2019, 431-464.

Vimercati Sanseverino, R. "La naissance de l'hagiographie marocaine: le milieu soufi de Fès et le Mustafād d'al-Tamīmī (m. 6o3/1206) ", Arabica 61 (2014), 278-308.

Vimercati Sanseverino, R. "Transmission, ethos and authority in Hadith scholarship: A reading of al-Qāḍī 'Iyāḍ's (476-544/1083-1149) handbook of Hadīth science 'The Elucidation of the principles of transmission and of the transcription of audition'", MIDEO: Volume Special sur l'autorité du Hadīth 34 (2019), 35-80.

Vimercati Sanseverino, R. Fès et sainteté, de la fondation à l'avènement du Protectorat (8o8-1912): Hagiographie, tradition spirituelle et héritage prophétique dans la ville de Mawlāy Idrīs, Rabat, Centre Jacques-Berque, 2014.

Zargar, C. A. The Polished Mirror. Storytelling and the Pursuit of Virtue in Islamic Philosophy and Sufism, Oxford, Oneworld, 2017.

Zouggar, N. "Les philosophes dans la prophétologie sunnite", Bulletin du Centre de recherche français à Jérusalem 23 (2012), http://journals.openedition.org/bcrfj/727o. 